\title{
Conflicted Counselors: Retaliation Protections for Attorney-Whistleblowers in an Inconsistent Regulatory Regime
}

\author{
Jennifer M. Pacella ${ }^{\dagger}$
}

Attorneys, especially in-house counsel, are subject to retaliation by employers in much the same way as traditional whistleblowers, often experiencing retaliation and loss of livelihood for reporting instances of wrongdoing involving their clients. Although attorney-whistleblowing undoubtedly invokes ethical concerns, attorneys who "appear and practice" before the Securities and Exchange Commission (SEC) are required by federal law to act as internal whistleblowers under the Sarbanes-Oxley Act (SOX) and report evidence of material violations of the law within the organizations that they represent. An attorney's failure to comply with these obligations will result in SEC-imposed civil penalties and disciplinary action. Current federal case law, however, is divided as to whether whistleblowers who report violations internally within their organizations, rather than to the SEC, are eligible for the robust retaliation protections available under the Dodd-Frank Wall Street Reform and Consumer Protection Act (Dodd-Frank). Given that external reporting by attorneys would run contrary to professional ethical mules in a number of states, lawyers risk getting caught in a catch-22 while attempting to comply with the conflicting regulatory regimes to which they are held. This Article highlights the importance of the compliance role of attorneywhistleblowers and addresses the catch-22 problem by analyzing whether the SOX attorney-reporting rules preempt conflicting state law. This Article proposes amendments to the SOX mules to clarify when external reporting is appropriate. It also considers a state-based solution to this conflict through the adoption of a modified version of Model Rule 1.13, the ethical rule governing

$\uparrow$ Professor Jennifer Pacella is an Assistant Professor of Law at the City University of New York (CUNY), Zicklin School of Business, Baruch College, in Manhattan, and an Adjunct Professor at State University of New York (SUNY) Buffalo Law School. The author would like to thank Eric Alden, Mark Bartholomew, Anya Bernstein, Guyora Binder, Kim Diana Connolly, Anthony Davis, Bruce Green, Michael Halberstam, Donald Joseph, Sung Hui Kim, Alex Long, Charles McCallum, Richard Moberly, Ramon Ragués i Vallès, Roy Simon, William H. Simon, John H. Schlegel, Robert Vaughn, Jay Weiser, and Benjamin Zipursky for their helpful comments on this article. The author also extends thanks to the participants of the Legal Ethics Scholars Roundtable, the 2015 Colloquium on Scholarship in Employment and Labor Law, the 90th Annual Meeting of the Academy of Legal Studies in Business, and the 2015 Annual Meeting of the Northeast Academy of Legal Studies in Business, for their beneficial comments during presentations of this article, as well as to Sean Kannengieser for his research assistance. 
the behavior of attorneys when they represent organizations and are called to act as whistleblowers.

Introduction

I. Attorney-Whistleblowing .....

A. The Reporting Duties of Attorneys and Repercussions for NonCompliance.

B. The Dodd-Frank Whistleblower Program and Judicial Interpretations

II. Weaknesses of Other Retaliation Protections for Attorney-

Whistleblowers. 508

A. State Law Protections for Retaliatory Discharge ………………....508

B. Statutory Protection for Attorney-Whistleblowers ..........................511 III.Conflicting Regulatory Regimes Governing Attorney Reporting ....... 516

A. ABA's 2003 Amendments to the Model Rules .................................. 516

B. How State Ethical Rules Compare to the Part 205 Rules and

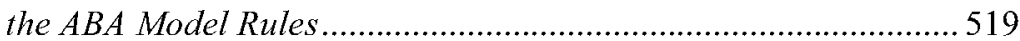

C. Ethical Rules of the Non-Adopting States ..................................... 525

IV. Proposed Considerations and Solutions ............................................. 527

A. Preemption of Part 205 Rules over Inconsistent State Ethical Rules

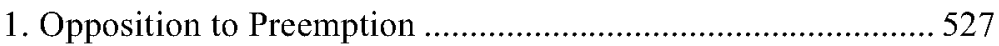

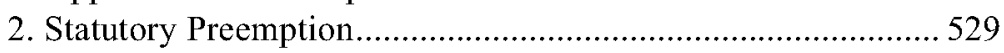

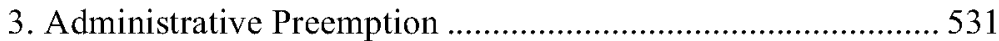

$B$. Clarity to the Attorney-Whistleblowing External Reporting

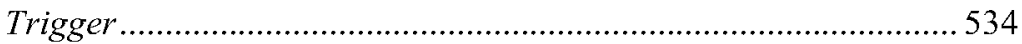

C. A Middle Ground: A State-Based Solution to Inconsistent

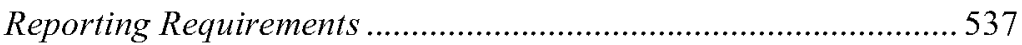

Conclusion.

Introduction

The year 2014 was declared "The Year of the Whistleblower" - a time in which whistleblowers privy to inside information about their employers' misconduct became empowered to report and remedy violations of the law. ${ }^{1}$ Despite recent trends heralding whistleblowers as essential players in effective

1. Terence Healy, 2014 -- The Year of the Whistleblower, ForBEs (Jan. 8, 2014), http:/www.forbes.com/sites/theemploymentbeat/2014/01/08/2014-the-year-of-the-whistleblower (warning employers of the perils of failing to address employee whistleblower concerns in light of increased regulatory whistleblower protections); see also Savaria Harris \& Mitka Baker, Lessons from the Year of the Whistleblower: A Changing Regulatory Regime, INSIDE COUNSEL (Jan. 16, 2015), http:/www. insidecounsel.com/2015/01/16/lessons-from-the-year-of-the-whistleblower-a-chang (describing the rise in government programs that protect and incentivize whistleblowers across various industries). 
compliance and moving away from negative labels like "snitch" and "traitor,"2 whistleblowers are still commonly victims of retaliation for their reporting." ${ }^{3}$ Recently, it has been said that "retaliation against whistleblowers remains alarmingly high," both on the rise nationally and at companies that outwardly appear committed to ethics and integrity. ${ }^{4}$ Retaliation against whistleblowers commonly emerges in the form of loss of employment, ostracism, alienation, or blacklisting from one's industry and results in both devastating financial and psychological effects for the whistleblower. ${ }^{5}$ Such retaliation occurs despite research showing that most whistleblowers report only internally to their employers and superiors, never venturing from the four walls of their places of employment to reveal information. ${ }^{6}$

Attorney-whistleblowers, especially in-house counsel, are no strangers to such negative reactions when they report internally on their clients' misconduct. Although attorneys tend not to fit the mold of the typical whistleblower, this group of professionals is required by federal law to blow the whistle internally, or "up-the-ladder," on organizational clients. In 2002, under Section 307 of the Sarbanes-Oxley Act (SOX), Congress ordered the Securities and Exchange Commission (SEC) to issue rules establishing

2. See Harris \& Baker, supra note 1; Jonathan Macey, Getting the Word Out About Fraud: A Theoretical Analysis of Whistleblowing and Insider Trading, 105 MICH. L. REV. 1899, 1940 $\mathrm{n} .53$ (2007) (describing the negative images typically used to describe whistleblowers); see also Yuval Feldman \& Orly Lobel, The Incentives Matrix: The Comparative Effectiveness of Rewards, Liabilities, Duties, and Protections for Reporting Illegality, 88 TEX. L. REV. 1151, 1159 (2010) (describing how the media has reshaped its view of whistleblowers as "heroic," signifying a move away from the traditional view in popular culture portraying whistleblowers as "lowlife[s] who betray[] a sacred trust largely for personal gain.").

3. National Business Ethics Survey of the U.S. Workforce, ETHICS RESOURCE CTR., 13 (2013), http://www.ethics.org/downloads/2013NBESFinalWeb.pdf. A 2013 study by the Ethics Resource Center that polled thousands of employees noted that retaliation against whistleblowers is a "widespread problem" and about $21 \%$ of those who report misconduct experience retaliation. Id.

4. Stephen Kohn, Retaliation Against Whistleblowers at All-Time High,"NAT'L WHistleBlowers LEGAL DEF. \& EDUC. FUND (Dec. 10, 2014), http:/www.whistleblowersblog.org/2014/12/articles/false-claims/retaliation-against-whistleblowers-at -all-time-high/ (citing Retaliation: When Whistleblowers Become Victims, ETHICS RESOURCE CTR. 2 (2012), http:/www.kkc.com/wp-content/uploads/2014/08/ERC_RETALIATION-When

-Whistleblowers-Become-Victims.pdf).

5. James Fanto, Whistleblowing and the Public Director: Countering Corporate Inner Circles, 83 OR. L. REV. 435, 438, 443-47, 462 (2004) (describing the common "inner circle" or group rejection of whistleblowers, who are susceptible to retaliation by threatening "groupthink" mentalities); Geoffrey Christopher Rapp, Beyond Protection: Invigorating Incentives for Sarbanes-Oxley Corporate and Securities Fraud Whistleblowers, 87 B.U. L. REV. 91, 118-25 (2007) (describing the many disincentives to blowing the whistle).

6. Christopher M. Matthews, Most Whistleblowers Report Internally, Study Finds, WALL ST. J. (May 30, 2012), http://blogs.wsj.com/corruption-currents/2012/05/30/most-whistleblowers -report-internally-study-finds/ (citing a survey of the Ethics Resource Center finding that only $2 \%$ of employee-whistleblowers reported outside of the companies for which they work without also reporting internally); see also Terry Morehead Dworkin \& Elletta Sangrey Callahan, Internal Whistleblowing: Protecting the Interests of the Employee, the Organization, and Society, 29 AM. BUS. L.J. 267 (1991) (noting that whistleblowers first commonly report internally); Gerard Sinzdak, An Analysis of Current Whistleblower Laws: Defending a More Flexible Approach to Reporting Requirements, 96 CALIF. L. REV. 1633, 1652 (2008). 
"minimum standards of professional conduct" for lawyers who "appear and practice" before the SEC. This mandate required attorneys to "report evidence of a material violation of securities law or breach of fiduciary duty," or other violations by their corporate clients to the chief legal counsel or chief executive officer, and, if no appropriate response is taken, up the ladder to the board of directors. ${ }^{7}$ Congress was prompted to enact this mandate in the wake of scandals like Enron and WorldCom that invited the question of "Where were the lawyers?", as clients committed devastating levels of fraud. The SEC issued these "Part 205 Rules," as they will be named herein, in 2003, imposing civil penalties and disciplinary consequences on attorneys who fail to adhere to the reporting rules. ${ }^{9}$

The Part 205 Rules also allow permissive disclosures under which attorneys may reveal to the SEC, without the issuer-client's consent, confidential information pertaining to the attorney's representation of the client in certain instances. ${ }^{10}$ Specifically, attorneys may provide the SEC with information about their clients "to the extent [they] reasonably believe necessary $[(a)]$ to prevent an issuer from committing a material violation of the law likely to cause substantial [financial] injury" to investors, (b) to stop an

7. 15 U.S.C. $\$ 7245$ (2012). Alternatively, an attorney may report such information to a "qualified legal compliance committee," if present, that meets certain specifications. See 17 C.F.R. $\S \S$ $205.2(\mathrm{k}), 205.3(\mathrm{c})(2003)$.

8. Stephen M. Bainbridge, Whistleblowers, Lawyers, and the Costs of Misconduct, in COMPlete Guide to SARBANES-OXley: Understanding How SARBANES-OXLey AfFects Your BusINESS 109 (2007). The legislative history of Section 307 of SOX acknowledges the fault of lawyers in such scandals:

[E]xecutives and accountants do not work alone. Anybody who works in corporate America knows that wherever you see corporate executives and accountants working, lawyers are virtually always there looking over their shoulder. If executives and/or accountants are breaking the law, you can be sure that part of the problem is that the lawyers who are there and involved are not doing their job.

148 CONG. REC. S6524-02 (daily ed. July 10, 2002) (statement of Sen. Edwards); see also Thomas G. Bost, Corporate Lawyers After the Big Quake: The Conceptual Fault Line in the Professional Duty of Confidentiality, 1 J. BUs. ENTREPRENEURSHIP \& L. 335, 388 (2008) (noting that the Part 205 Rules are based on "the implicit premise that even though the lawyer's primary allegiance is to his client, he is accountable to a significant degree to those third parties who have legitimate interests in being protected against the client's misdeeds."); Sara B. Smith, Sarbanes-Oxley Act, Section 307 - The Price of Accountability: How Will Section 307 Affect the Role of the Corporate Attorney? 107 W. VA. L. REV. 901,915 (2005) (noting that Section 307 of SOX "holds lawyers accountable" for reporting violations to avoid another Enron scandal). Bost takes the view that the SEC may have disregarded the "optimum vision of lawyering" in adopting these rules, which would have prioritized allowing the lawyer to establish the necessary degree of trust to serve as a counselor or advisor for the client. Bost, supra, at 388 .

9. 17 C.F.R. $\$ 205.6$ (2003). Disciplinary action by the SEC may include an attorney being censured or the denial, either temporarily or permanently, of the privilege of appearing or practicing before the SEC. Junior attorneys appearing and practicing before the SEC are also subject to the rules and fulfill their duties by reporting material violations to their supervisory attorneys, who must then comply with the up-the-ladder reporting requirements. See $i d$. 205.5(c), (d); Richard M. Humes, Remarks of an SEC Associate General Counsel, 57 CASE W. RES. L. REV. 341 (2007) (discussing the types of disciplinary proceedings that the SEC has brought against attorneys).

10. 17 C.F.R. $\S 205.3(2003)$. 
issuer from committing perjury, or (c) to rectify the consequences of a material violation for which the attorney's services were used. ${ }^{11}$ Currently, eighteen states, as well as Washington, D.C., do not permit the same type of external reporting that is available under the Part 205 Rules. ${ }^{12}$ Thus, attorneys who are admitted to the bar in these jurisdictions and also appear and practice before the SEC must be cautious of utilizing the permissive disclosure option under the Part 205 Rules, lest they violate the duty of confidentiality that they owe to clients.

In 2010, Congress enacted the Dodd-Frank Wall Street Reform and Consumer Protection Act (Dodd-Frank), ${ }^{13}$ which, in addition to implementing extensive financial regulatory reform measures, introduced a robust whistleblower program providing stronger protections from retaliation than are available under SOX's earlier whistleblower program. Unlike the weaker retaliation protections and administrative remedies available under SOX, DoddFrank allows for a direct private right of action in federal district court for whistleblowers alleging retaliation by their employers and a lengthy statute of limitations; remedies include reinstatement of employment, compensation for litigation costs, and double back pay. ${ }^{14}$ Currently, federal appellate case law is divided as to whether whistleblowers who report only internally are protected by these generous retaliation protections. The Fifth Circuit's 2013 decision in Asadi v. G.E. Energy ${ }^{15}$ excluded internal whistleblowers from relief under Dodd-Frank ${ }^{16}$ and the Second Circuit disagreed in 2015. ${ }^{17}$ Therefore, as the law currently stands, attorney-whistleblowers who experience retaliation for following their internal reporting duties under the Part 205 Rules might not be protected under Dodd-Frank; if so, this would require them to rely on the weaker retaliation protections of SOX and state laws. As might be expected, if attorney-whistleblowers were to make external reports to the SEC under the Part 205 Rules to ensure Dodd-Frank protection, they would risk disciplinary action from states to which they are admitted that have differing rules - thereby prompting a catch-22 scenario for attorneys subject to these conflicting regulatory regimes. Legal practitioners and commentators have noted the practical problems that these conflicts create for attorneys who appear and practice before the SEC-in effect, they bar attorneys admitted in jurisdictions with conflicting rules from ever utilizing the permissive disclosure option of

11. Id.

12. See infra Part III.B.

13. Dodd-Frank Wall Street Reform and Consumer Protection Act of 2010, Pub. L. No. 111-203, 124 Stat 1376.

14. Compare id, with Sarbanes-Oxley Act of 2002, Pub. L. No. 107-204, 116 Stat 745 .

15. 720 F.3d 620 (5th Cir. 2013).

16. See id.; see also Jennifer M. Pacella, Inside or Out? The Dodd-Frank Whistleblower Program's Antiretaliation Protections for Internal Reporting, 86 TEMP. L. REV. 721 (2014).

17. Berman v. Neo@Ogilvy LLC, 801 F.3d 145 (2d Cir. 2015). 
the Part 205 Rules. ${ }^{18}$ These concerns have become even more relevant now that Dodd-Frank offers bounty rewards for whistleblowers. Although there is a current debate as to whether attorney-whistleblowers are eligible to receive a bounty under Dodd-Frank given exceptions in the statute that would appear to make such rewards available in limited circumstances, ${ }^{19}$ commentators have expressed concern that the availability of a bounty in this manner may incentivize attorneys to rely on the permissive disclosure options of the Part 205 Rules to report confidential client information to the SEC for a financial reward. $^{20}$

This Article will examine the lack of uniformity among the permissive disclosure rules of the Part 205 Rules, the American Bar Association's Model Rules of Professional Conduct (Model Rules), and state ethical rules, while

18. See, e.g., Naseem Faqihi, Choosing Which Rule to Break First: An In-House Attorney Whistleblower's Choices After Discovering a Possible Federal Securities Law Violation, 82 FORDHAM L. REV. 3341, 3389-90 (2014) (discussing the dilemmas of in-house counsel, who cannot rely on one uniform set of rules in determining how to act to avoid future retaliation and comply with reporting obligations when clients are violating the federal securities laws); Greg Keating et al., Retaliation and Whistleblower Claims by In-House Counsel, LITTLER REPORT 19 (Mar. 2013) (noting the practical difficulties of whistleblower situations involving a company's in-house counsel given that "it is the job of those employees to disclose any known or suspected misconduct"); G. Thomas Stromberg, Jr. et al., Lawyer Conduct Rules Under Sarbanes-Oxley \& State Bars: Conflicts to Navigate? (Wash. Legal Found., Working Paper No. 132, 2005) (noting that, if admitted in jurisdictions with conflicting rules, attorneys would need to disregard the Part 205 Rules's permissive disclosure option); William McLucas et al., Attorneys Caught in the Ethical Crosshairs: Secretkeepers as Bounty Hunters under the SEC Whistleblower Rules, 46 Sec. Reg. \& L. Rep. (BNA) 711, 714 (2014), http:/www.wilmerhale.com/uploadedFiles/WilmerHale_Shared_Content/Files/PDFs/Attorneys-Caughtin-the-Ethical-Crosshairs-BNA-Law-Report-4-14-2014.pdf (explaining these conflicting ethical rules and suggesting practical solutions for attorneys and clients); infra Parts III, IV.A.

19. See Jennifer M. Pacella, Advocate or Adversary? When Attorneys Act as Whistleblowers, 28 GEO. J. LEGAL ETHICS 1027 (2015) (discussing the ethical concerns associated with attorney-whistleblowers receiving a bounty under Dodd-Frank); see also Kathleen Clark \& Nancy J. Moore, Buying Voice: Financial Rewards for Whistleblowing Lawyers, 56 B.C. L. REV. 1697 (2015) (analyzing the doctrinal questions of an attorney's ability to receive whistleblower bounty awards under federal statutes); Barry R. Temkin \& Ben Moskovits, Lawyers as Whistleblowers Under the DoddFrank Wall Street Reform Act, N.Y. ST. B. Ass'N J., July/Aug. 2012, at 10 (advising securities lawyers to consider the conflicting ethical and fiduciary duties they face).

20 See, e.g., Temkin \& Moskovits, supra note 19, at 21 (noting the "personal conflict [] posed by [] Dodd-Frank" that emerges for corporate attorneys when a bounty award may be available); Robert J. Malionek \& Keith A. Cantrelle, Read Before Whistleblowing: What Every Lawyer Needs to Know, HARV. L. F. ON CORP. Gov. \& FIN. REG. (Nov. 14, 2013), http://corpgov.law.harvard.edu/2013/11/14/read-before-whistleblowing-what-every-lawyer-needs-to

-know/ (discussing the ethical repercussions in New York of collecting a bounty as an attorneywhistleblower); McLucas et al., supra note 18, at 11 (noting that the bounty program of Dodd-Frank may create an incentive for lawyers to use the Part 205 Rules's permissive disclosures to report confidential client information to the SEC for purposes of obtaining a bounty); Nick Morgan \& Haley Greenberg, Is the SEC Encouraging Unethical Whistleblowing by Counsel?, THOMSON REUTERS (Aug. 25, 2014), http://blog.thomsonreuters.com/index.php/is-the-sec-encouraging-unethical-whistleblowing -by-counsel/ "While the Dodd-Frank bounty provisions increase the incentives for attorneys to act as whistleblowers at their clients' expense, it is unclear whether those incentives outweigh the risks and burdens associated with taking such actions."). The question of whether attorney-whistleblowers should be eligible to collect bounty rewards under Dodd-Frank is beyond the scope of this article. I have addressed this particular question in a separate article. See Pacella, supra note 19. In that article, I noted that an issue related to the bounty question is whether retaliation protections are available under the statute for whistleblowing lawyers subject to the Part 205 Rules, which I will address herein. 
focusing on attorneys working in-house who are obligated to act as internal whistleblowers under SOX and face retaliation for doing so. Part I will discuss the mismatch between the duties imposed on attorneys under the Part 205 Rules and the lack of sufficient retaliation protections for adhering to those duties. This Section will discuss the importance of ensuring ample retaliation protections for attorneys in light of their role in ensuring compliance through "new governance" approaches to regulation, and will discuss the catch-22 problem that varying judicial interpretations of Dodd-Frank have created. Part II will examine the evolution of legal developments for retaliation protections allowing attorneys to avail themselves of remedies under state law for retaliatory discharge and statutes like SOX, while discussing the lack of sufficient protections under these sources of law.

Part III will examine the American Bar Association's reaction to the Part 205 Rules in 2003 and the amendments it made to its own Model Rules to mirror SOX's requirements. This Section will analyze the ways in which the legal obligations of attorneys subject to the Part 205 Rules leave open the possibility of conflict with the ethical rules of the various states that either do not allow the same disclosures that are permitted under the Part 205 Rules or have not adopted the American Bar Association's Model Rules regarding "Organization as Client." 21 This Section provides a novel analysis of the various nuances in permissive disclosure rules across several states.

Although no court has yet determined whether the Part 205 Rules preempt conflicting state ethical rules, in Part IV, this Article argues that the former would prevail, requiring states to yield to the federal standards governing attorneys who appear and practice before the SEC. Part IV also suggests amendments to improve the Part 205 Rules to qualify the "reasonable belief" standard and reporting trigger to allow an attorney to reveal externally only when all internal reporting mechanisms have been exhausted. Finally, this Section will explore a state-based solution to achieve more uniformity in this context-specifically, the adoption of a modified version of Model Rule 1.13 by the states whose ethical rules directly conflict with the Part 205 Rules.

\section{Attorney-Whistleblowing}

\section{A. The Reporting Duties of Attorneys and Repercussions for Non-Compliance}

The Part 205 Rules impose affirmative reporting duties on attorneys to act as crucial players in ensuring their organizational clients' adherence to the law. Given the importance of such reporting to self-regulation and the fact that lawyers in this arena are subject to SEC disciplinary actions for noncompliance, their reporting obligations under the Part 205 Rules should be matched with rights that unquestionably provide retaliation protection for

21. See Model Rules of PROF'L ConduCT r. 1.13 (2015). 
fulfilling these duties. Instead, attorneys in this arena, specifically in-house counsel, have suffered or feared retaliatory measures.

When Congress enacted Section 307 in 2002, thereby mandating the SEC to adopt "minimum standards of professional conduct" for attorneys appearing and practicing before the agency, ${ }^{22}$ it did so with the goal of reminding lawyers "who their client is" after an era in which executives appeared to uninhibitedly proceed with fraud in scandals like Enron. ${ }^{23}$ The Part 205 Rules emphasize that lawyers owe fiduciary duties to the organizations they represent, including their investors and shareholders, rather than merely to the parties whom attorneys may see most regularly. ${ }^{24}$ To fulfill those duties, the Part 205 Rules require lawyers to take steps to mitigate overall damage to the organization by alerting key executives and the board of directors to material violations of the law that the lawyer discovers. ${ }^{25}$

In this vein, the up-the-ladder duties of attorneys under the Part 205 Rules fall within modern-day "new governance" regulatory regimes that emphasize self-policing and self-regulation as essential to effective corporate governance. ${ }^{26}$ As a number of scholars have noted, "new governance" encompasses a range of modern-day developments in the world of corporate governance, regulatory reform, and compliance. ${ }^{27}$ While "traditional" or "old" governance is described as "top-down, rule-bound, centralized, [and]

22. Pub. L. No. $107-204, \S 307,116$ Stat. 745,784 (2002) (codified at 15 U.S.C. $\S$ 7245 (2012)) (emphasis added).

23. 148 Cong. Rec. S6524-02 (daily ed. July 10, 2002) (statement of Sen. Edwards).

24. See id. Christin M. Stephens, Sarbanes-Oxley and Regulations of Lawyers' Conduct: Pushing the Boundaries of the Duty of Confidentiality, 24 ST. LOUS U. PUB. L. REV. 271, 298 (2005) (noting the importance of the corporate attorney's obligation to the "public at large, as well as to his or her client").

25. See 148 Cong. Rec. S6524-02 (daily ed. July 10, 2002) (statement of Sen.

Edwards).

26. See On Amir \& Orly Lobel, Stumble, Predict, Nudge: How Behavioral Economics Informs Law and Policy, 108 COLUM. L. REV. 2098, 2127 (2008) (reviewing RICHARD H. THALER \& Cass R. SunsteIn, Nudge: Improving Decisions About Health, Wealth, and HapPiness (2008) and noting that new governance approaches "have received various expressions and terms in the law and regulation literature, signifying the myriad of recent regulatory approaches designed to enhance problem solving, self-regulation, and government-industry cooperation").

27. Lisa T. Alexander, Symposium, Reflections on Success and Failure in New Governance and The Role of the Lawyer, 2010 WIS. L. REV. 737, 738-39 (describing "new governance" as "def[ying] precise definition and "encompass[ing] familiar recent governance innovations such as privatization, devolution, decentralization, public-private partnerships, and stakeholder collaboration"); Cristie L. Ford, New Governance, Compliance, and Principles-Based Securities Regulation, 45 AM. Bus. L.J. 1, 27 (2008) (noting that " $[t]$ he term New Governance has emerged as an overarching moniker to refer to a new approach in legal scholarship" emphasizing the way in which change occurs in "complex real-life social systems."); Orly Lobel, The Renew Deal: The Fall of Regulation and the Rise of Governance in Contemporary Legal Thought, 89 MINN. L. REv. 342, 344 (2004) (describing the "new governance" model as supportive of "the replacement of the New Deal's hierarchy and control with a more participatory and collaborative model, in which government, industry, and society share responsibility for achieving policy goals."); Robert C. Bird \& Stephen Kim Park, Turning Corporate Compliance into Competitive Advantage, 19 U. PA. J. BUS. L. (forthcoming 2017) (collectively referring to new governance-related measures as "Collaborative Regulation" involving ongoing communication between the regulator and regulated entity and a system focused on principles-based regulation). 
government-run,, 28 and may have best described the regulatory regime in place prior to Enron, ${ }^{29}$ new governance is built on self-regulation, internal reporting, and administrative governance in which various stakeholders, both private and public, collaborate to implement and ensure effective compliance with the law through transparency, increased dialogue between players in the industry, and processes focused on inclusive decision-making. ${ }^{30}$ Thus, new governance turns away from "traditional" and adversarial legal enforcement methods like "litigation, arbitration, or hard bargaining.", Instead of focusing on the attorney's role as an advocate in an adversarial setting, it emphasizes the attorney's role as an advisor focused on ensuring compliance with the law. ${ }^{32}$

The SEC has a long history of promoting self-regulation and self-policing through internal reporting, as is visible through its delegation of responsibility for governance of national securities exchanges and broker-dealers to private self-regulatory organizations, or SROs, like FINRA. ${ }^{33}$ In addition, SOX implemented many measures that are built on self-regulation through internal controls, such as the requirement for public companies to establish internal reporting channels to catch instances of wrongdoing, even anonymously, and

28. Wendy A. Bach, Governance, Accountability, and the New Poverty Agenda, 2010 WIS. L. REV. 239, 255-56; Bird \& Park, supra note 27, at 30 (describing traditional governance or command-and-control regulation as dependent on coercive government authority "to mandate the regulated firm's compliance with statutorily defined regulatory objectives through the threat of investigation, civil fines, and criminal prosecution").

29. See Troy A. Paredes, Too Much Pay, Too Much Deference: Behavioral Corporate Finance, CEOs, and Corporate Governance, 32 FLA. ST. U. L. REV. 673, 744 n.271 (2005) (noting that Sarbanes-Oxley implemented a "host of new governance and disclosure practices").

30. See, e.g., Wendy A. Bach, Mobilization and Poverty Law: Searching for Participatory Democracy amid the Ashes of the War on Poverty, 20 VA. J. SOC. POL'Y \& L. 96, 110 (2012) (noting that "government acts not as a centralized rule-maker but as a facilitator of the experimentalist enterprise" in a new governance model); Cynthia Estlund, Corporate Self-Regulation and the Future of Workplace Governance, 84 CHI.-KENT L. REV. 617, 624 (2009) ("[E]ffective selfregulation depends partly on effective stakeholder participation within self-regulatory systems"); Orly Lobel, Citizenship, Organizational Citizenship, and the Laws of Overlapping Obligations, 97 CALIF. L. REV. 433, 472 (2009); Saule T. Omarova, Wall Street As Community of Fate: Toward Financial Industry Self-Regulation, 159 U. PA. L. REV. 411, 427-28 (2011) (discussing that the new governance paradigm has replaced "the old notion of 'regulation' as a top-down exercise of power through a rigidly hierarchical structure").

31. Alexander, supra note 27, at 741-42 (citing Louise G. Trubek, New Governance and Soft Law in Health Care Reform, 3 IND. HEALTH L. REV. 137, 149 (2006) and noting that "traditional 'hard law' approaches have proved inadequate in many instances [while] new governance approaches allow learning and feedback and create alliances").

32. See id; see also Susan D. Carle, Progressive Lawyering in Politically Depressing Times: Can New Models for Institutional Self-Reform Achieve More Effective Structural Change?, 30 HARV. J. L. \& GENDER 323, 341 (2007) (noting that new governance involves "freeing lawyers from their traditional, cautious, litigation-wary stance so that they can become more creative problem solvers"); William H. Simon, Solving Problems vs. Claiming Rights: The Pragmatist Challenge to Legal Liberalism, 46 WM. \& MARY L. REV. 127 (2004) (discussing new conceptions of lawyering).

33. See Jennifer M. Pacella, If the Shoe of the SEC Doesn't Fit: Self-Regulatory Organizations and Absolute Immunity, 58 WAYNE L. REV. 201, 205-07 (2012) (noting that, prior to the enactment of the Securities Exchange Act of 1934, securities exchanges were completely self-governing for nearly 140 years); see also 15 U.S.C. $\$ \$ 78 \mathrm{a}-78 \mathrm{~b}$ (2012) (discussing the need for the regulation of securities transactions as conducted over securities exchanges and over-the-counter markets). 
the Section 301 requirement for boards of directors' audit committees to establish procedures for receiving and managing complaints about accounting and auditing controls. ${ }^{34}$

Attorneys appearing and practicing before the SEC who are subject to the Part 205 Rules play an important role in these efforts because they operate in a unique advisory context focused on self-regulation. ${ }^{35}$ Effective self-regulation and internal reporting has significant positive effects on business organizations, including the avoidance of amplified financial harm to the organization, excessive or damaging penalties, bad publicity, litigation, and losses for shareholders. ${ }^{36}$ Attorneys are instrumental in these efforts by independently deciding whether their client's conduct is unlawful, advising the client about such determinations, and taking action to prevent harm to the organization itself by escalating knowledge of the illegal conduct to executives and board members so that it may be properly addressed, ${ }^{37}$ thereby mitigating overall damage to the entity. 38

The Part 205 Rules represent an increasing trend among lawyers, especially those who represent corporate organizations, to move away from "the traditionally rigid notion of attorney-client confidentiality to a new conception of professional loyalty" focused on "substantive compliance for the

34. See 15 U.S.C. $\$ 78 \mathrm{j}-1(\mathrm{~m})(4)$ (2012) (requiring corporations to establish procedures for employees to report confidential and anonymous information relating to accounting or auditing misconduct to the audit committee); id. $\S 7262$ (governing the management assessment of internal controls); see also Diane Ambler et. al., The \$7 Trillion Question: Mutual Funds \& Investor Welfare, 1 J. BUS. \& TECH. L. 23, 32 (2006) (statement of panelist Earl Weiner) (discussing the SEC's requirement for participants in the fund industry to hire compliance officers or increase the responsibilities of current internal compliance officers, "so as to provide compliance personnel whose loyalties are to the independent directors"). The SEC also emphasizes self-regulation as it pertains to compliance with the Foreign Corrupt Practices Act, which imposes accounting and internal control provisions for enforcement on audit committees and emphasizes voluntary disclosures by companies to compensate for the agency's staff and budgetary restrictions. See Daniel J. Grimm, The Foreign Corrupt Practices Act in Merger and Acquisition Transactions: Successor Liability and Its Consequences, 7 N.Y.U. J. L. \& BUS. 247, 263-64 (2010); Michael Volkov, Voluntary Disclosure: The Continuing FCPA Debate, LAw360 (Nov. 21, 2014), http:/www.law360.com/articles/595478/voluntary-disclosure-the -continuing-fcpa-debate.

35. Robert A. Desilets, Jr., The Model Rules of Professional Conduct and the Securities Attomey: Confidentiality, Confusion and the Need for Change, 23 CAP. U. L. REV. 611, 63234 (1994) ("Given this difference,] new standards must be formulated to enumerate those ethical criteria to which the securities attorney is bound."); William Kenneth C. Dippel, Attorney Responsibility and Carter Under SEC Rule 2(e): The Powers That Be and the Fear of the Flock, 36 SW. L.J. 897, 900 n.22 (1982); Sung Hui Kim, Lawyer Exceptionalism in the Gatekeeping Wars, 63 SMU L. REV. 73, 120$21(2010)$.

36. See Norman D. Bishara et al., The Mouth of Truth, 10 N.Y.U. J. L. \& Bus. 37, 76 (2013) (discussing internal reporting as "more efficient and effective" than external reporting if the "primary goals of whistleblowing are exposing and curtailing wrongdoing"); see also Corporate LawSecurities Regulation-Congress Expands Incentives for Whistleblowers to Report Suspected Violations to the SEC, 124 HARV. L. REV. 1829, 1835-36 (2011) (discussing the benefits to companies of internal reporting).

37. Paula Schaefer, Overcoming Noneconomic Barriers to Loyal Disclosure, 44 AM. BUS. L.J. 417, 443-45 \& n. 107 (2007).

38. Id. 
corporation at large."39 Attorneys working in-house for a corporation are uniquely positioned to gain knowledge of wrongdoing given their familiarity with the organization's operations and professional expertise, ${ }^{40}$ and to encourage clients to address wrongdoing internally. ${ }^{41}$ When the organization insists on wrongdoing, in-house attorneys, whose central role is to maintain the core values of the organization, ${ }^{42}$ risk facing personal liability for unwillingly assisting the client in continuing with the misconduct, ${ }^{43}$ which may render them "accountable actors" under the federal securities laws. ${ }^{44}$

Attorneys who fail to adhere to the Part 205 Rules are subject to civil penalties from the SEC, including censure, or temporary or permanent denial of the ability to appear or practice before the agency. ${ }^{45}$ They may also face civil liability or criminal charges if they assist clients with fraudulent schemes as primary violators of the federal securities laws, as is clear from the many such actions that have been brought by third-party investors and the SEC against lawyers. ${ }^{46}$ In recent years, the SEC has aggressively targeted in-house counsel for securities violations, holding some liable for primary violations of the securities laws. ${ }^{47}$ In addition to direct SEC enforcement measures, the SEC has the authority to discipline lawyers appearing before it pursuant to SEC Rule 102(e) who lack "character or integrity,' or who have 'engaged in unethical or

39. Lobel, supra note 30 , at 483 .

40. Orly Lobel, Lawyering Loyalties: Speech Rights and Duties Within Twenty-First Century New Governance, 77 FORDHAM L. REV. 1245, 1264-65 (2009); see also Elizabeth C. Tippett, The Promise of Compelled Whistleblowing: What the Corporate Governance Provisions of Sarbanes Oxley Mean for Employment Law, 11 EMP. RTS. \& EMP. POL'Y J. 1, $37-38$ (2007) (noting that attorneys are "accustomed to navigating grey areas of fact and law" to discern what is legal, unlike managers, directors, or auditors).

41. See Stephen Fraidin \& Laura B. Mutterperl, Advice for Lawyers: Navigating the New Realm of Federal Regulation of Legal Ethics, 72 U. CIN. L. REV. 609, 613 (2003) (noting the essentiality of lawyers to "corporate activity and to the interpretation and implementation of the laws relating to corporate governance and transactions").

42. David B. Wilkins, Team of Rivals? Toward a New Model of the Corporate Attorney-Client Relationship, 78 FORDHAM L. REV. 2067, 2117 (2010) (noting that many general counsels have "assert[ed] that this is at the core of what they do").

43. See supra Part IV.A.1. See also Lobel, supra note 40, at 1267 (noting that the Part 205 Rules strengthen the notion of "in-house attomeys as gatekeepers of organizational ethical behavior").

44. See Lobel, supra note 40, at 1267 (citing JOHN C. COFFEE, JR., GATEKEEPERS: THE Professions AND CoRPorate GOVERNANCE 195 (2006)).

45. 17 C.F.R. $\$ 205.6(\mathrm{a})$, (b) (2003).

46. Lisa H. Nicholson, A Hobson's Choice for Securities Lawyers in the Post-Enron Environment: Striking a Balance Between the Obligation of Client Loyalty and Market Gatekeeper, 16 GEO. J. LEGAL ETHICS 91, 102-03 \& n.54 (2002); 15 U.S.C. § 78(t) (2012) (authorizing the SEC to bring actions in federal district court against any person for violations of the federal securities laws); $i d$. $\S$ $78(\mathrm{u})(\mathrm{d})(1)$ (authorizing the SEC to implement injunction proceedings or monetary penalties in civil actions); see SEC v. Nat'l Student Mktg. Corp., 457 F. Supp. 682 (D.D.C. 1978) (in which the SEC sought civil injunctive relief against attorneys who allowed a merger involving their clients to proceed with materially misleading information).

47. Daniel R. Coquillette \& Judith A. McMorrow, Zacharias's Prophecy: The Federalization of Legal Ethics Through Legislative, Court, and Agency Regulation, 48 SAN DIEGO L. REV. 123, 134 (2011). 
improper professional conduct,' or 'willfully violated, or willfully aided and abetted the violation of any provision of the Federal securities laws or the rules and regulations thereunder.",48

Attorneys who practice in the securities arena before the SEC are not always successful in dissuading clients from misconduct, giving rise to situations in which lawyers may be "unwittingly co-opted into the clients" criminal or fraudulent schemes-either by being cajoled into believing that compliance is occurring or, by allowing too much time to pass between their discovery and any ensuing actions undertaken on the part of lawyers." lawyers' ethical duties not to assist clients in committing crime or fraud, ${ }^{50}$ they must take steps to proactively dissuade clients from engaging in wrongdoing, lest they become entangled in the wrongdoing and subject themselves to SEC discipline. ${ }^{51}$ Given these repercussions, it is essential that lawyers are protected from retaliation for adhering to these duties. As Orly Lobel has discussed, "[i]ndividual internal dissent is necessary to complement requirements of systematic self-monitoring." 52

There have been many instances of attorneys, especially in-house counsel, experiencing or fearing retaliation for following their ethical duties, and whistleblower claims brought by in-house counsel have drastically increased in recent years. ${ }^{53}$ Alex Long has provided an extensive study of the numerous cases that attorneys have brought in past years for experiencing retaliation after

48. Id:; 17 C.F.R. $\S 201.102(\mathrm{e})(1)(2010)$.

49. See Nicholson, supra note 46, at 129 (discussing that securities lawyers are not always able to dissuade clients from improper conduct).

50. MODEL RULES OF PROF'L CONDUCT r. 1.2(d) (2013).

51. See Nicholson, supra note 46, at 129-30 (noting that lawyers who "stubbornly continue to counsel a client against the misconduct, knowing that such advice is 'falling upon deaf ears" are likely to face liability).

52. Lobel, supra note 30, at 473; see also Lobel, supra note 40, at 1249 ("Even more than in the past, protections for employee whistleblowing are necessary to complement programs of systematic self-reporting.").

53. See, e.g., Alex B. Long, Retaliatory Discharge and the Ethical Rules Governing Attorneys, 79 U. COLO. L. REV. 1043 (2008) (noting numerous cases confirming that attorneys reporting misconduct, either internally or externally, are faced with retaliatory discharge); Kim $\mathrm{T}$. Vu, Conscripting Attorneys to Battle Corporate Fraud Without Shields or Armor? Reconsidering Retaliatory Discharge in Light of Sarbanes-Oxley, 105 MICH. L. REV. 209, 213-214 (2006) (describing the case of John E. Isselmann, Jr., former general counsel of Electro Scientific Industries Incorporated, who attempted to report accounting fraud internally but later resigned for fear for retaliation); Brandon Gee, Supreme Court Ruling Raises Questions over Lawyer-Whistleblowers, NEw ENGLAND IN-HOUSE (May 6,2014 ), http://newenglandinhouse.com/2014/05/06/supreme-court-ruling-raises-questions-over-lawyer -whistleblowers/ (noting a "huge uptick over the past two years in whistleblower claims brought by in -house counsel and compliance officers"); see also Vu, supra (citing Letter from Elaine J. Mittleman, Comments on Proposed Rule Implementation of Standards of Professional Conduct for Attorneys, File No. 27-45-02, (Apr. 17, 2003), https://www.sec.gov/rules/proposed/s74502/ejmittleman1.htm ("The obvious and severe retaliation that an attorney or a law firm may face as a result of reporting surely serves as a strong disincentive to making reports or an incentive to interpret situations in a way that reporting is not required.")). 
adhering to their professional ethical duties. ${ }^{54}$ Inside counsel, as employees of the business organizations for which they work, are especially vulnerable to the devastating effects of whistleblower retaliation in ways that external counsel, who rely on a variety of clients, are not. ${ }^{55}$ An in-house counsel's relationship with his/her organization as client is much the same as other employeewhistleblowers, as the lawyer is dependent on the company for income and benefits and is subject to its control with respect to hours, salary, promotion, and personnel procedures. ${ }^{56}$

As Sung Hui Kim has discussed, inside counsel depend on only one client- "[i]f they get fired, they lose their entire income, insurance, and basic livelihood. If pensions or stock options have not vested, then enormous sums of money can be forfeited as well. Even worse, if they get fired for whistleblowing, they may get blacklisted...."57 Other common forms of retaliation include: pressure to facilitate, rather than thwart, corporate transactions; pressure to conform to the values of the organization and be a "team player"; and pressure to please management in an effort to ensure performance-based bonuses. ${ }^{58}$ As Eric Alden has expressed, the CEO and the CFO, to whom general counsel are often subordinate, may outright fire the general counsel for failing to facilitate transactions "or, in the more subtle but equally effective manner of those sophisticated in the fine art of retaliation, verbally, or

54. See Long, supra note 53, at 1049-66 (examining the various categories of attorney-whistleblowing situations and finding the "basic theme" in nearly all cases is that attorneys are forced to decide between retaining their employment and ethically engaging in law practice).

55. See Sara A. Corello, In-House Counsel's Right to Sue for Retaliatory Discharge, 92 COLUM. L. REV. 389, 405-09 (1992) (describing the differences between inside and outside counsel).

56. Id. at 405-06 (arguing that in-house counsel should be considered to fit the definition of "employee" for the purposes of statutory and common law protections from retaliatory discharge); see also Lobel, supra note 40 , at 1249 (noting the complete economic dependence of inhouse counsel on their employers). But see Balla v. Gambro, 584 N.E.2d 104, 108-09 (Ill. 1991) (taking the view that attorneys are not subject to retaliation protections given the relationship of trust and confidence that they maintain as part of the attorney-client relationship).

57. Sung Hui Kim, The Banality of Fraud: Resituating the Inside Counsel as Gatekeeper, 74 FORDHAM L. REV. 983, $1005-06$ (2005); see also Vu, supra note 53, at 236 (noting the importance of retaliation protections for attorneys, especially in light of their reporting duties under SOX).

58. Kim, supra note 57, at 1006-08, 1026 (discussing the conformity pressures that may prompt inside lawyers to remain silent in the face of misconduct, including "the desire to avoid stigma and maintain social capital"); see also David B. Greenberger et al., Oppositionists and Group Norms: The Reciprocal Influence of Whistleblowers and Co-workers, 6 J. BUS. ETHICS 527, 531-33 (1987) (noting that whistleblowing itself will be less likely to occur in "highly cohesive groups," which exert pressure on individuals to conform, especially when the potential whistleblower highly depends on the group). In this way, in-house lawyers may be expected to act in accordance with the expectations of the officers that oversee them. See Mark A. Sargent, Lawyers in the Moral Maze, 49 VILL. L. REV. 867, 879 (2004) (discussing the in-house counsel's vulnerability to "adopting the same occupational morality as the managers with whom they work, because they are subject to the same social exigencies, power struggles, personal uncertainties and demands of expediency that characterize the corporate bureaucratic organization"). 
otherwise, signal that the [general counsel's] continued employment in that position is no longer desired." 59

Robust retaliation protections for in-house attorneys subject to the Part 205 Rules are also necessary to ensure that attorneys will raise concerns or voice opposition to protect the organizational client without fear of reprimand from corporate officers or directors who may wish to persist with misconduct. ${ }^{60}$ As will be discussed in the next section, retaliation protections available to attorney-whistleblowers who report internally are neither assumed nor guaranteed.

\section{B. The Dodd-Frank Whistleblower Program and Judicial Interpretations}

One of the most recent developments in whistleblower protections is Dodd-Frank, which was enacted in 2010 not only to implement sweeping reforms in financial regulation but also to introduce a comprehensive whistleblower program to motivate insiders to help the government identify wrongdoers. $^{61}$ The whistleblower provisions of Dodd-Frank, codified at 15 U.S.C. $\$ 78 u-6$, were aimed at eliminating the administrative hurdles of the earlier SOX whistleblower program by offering a direct cause of action in federal court for retaliation. ${ }^{62}$ Subsection (h) of 15 U.S.C. $\$ 78$ u-6 protects whistleblowers who experience retaliation for (i) providing information to the SEC, (ii) testifying or assisting in SEC investigations or related actions, or (iii) "making disclosures that are required or protected under the Sarbanes-Oxley Act of 2002," other specified federal laws, or any law, rule, or regulation subject to the SEC's jurisdiction. ${ }^{63}$ The enforcement provisions of Dodd-Frank are noticeably stronger than those of SOX. Whistleblowers under the former may directly sue in federal court without a need to exhaust administrative remedies (as SOX requires), and are subject to a lengthy statute of limitations of six years after the date on which the retaliation occurred (compared to SOX's 180 days). ${ }^{64}$ In addition, relief under the statute is much more generous than under SOX, offering double back pay with interest (whereas SOX offers only one-time back pay). ${ }^{65}$

59. Eric Alden, Blocking the Ax: Shielding Corporate Counsel from Retaliation as an Alternative to White Collar Hypercriminalization, 36 U. HAW. L. REV. 95, 102 (2014); see also Robert T. Begg, Whistleblower Law and Ethics, in ETHICAL STANDARDS IN THE PUBLIC SECTOR: A GUIDE FOR Government Lawyers, Clients, AND Public OfFicials 210-11 (Patricia Salkin ed., A.B.A. 2008) (discussing the ethical dilemmas that in-house counsel face as internal whistleblowers).

60. See Kim, supra note 57, at 1005-06; see also Corello, supra note 55, at 409.

$(2010)$

61. S. REP. No. 111-176, at 110-11 (2010); see also H.R. Res. 4173, 111th Cong.

62. 15 U.S.C. $\$ 78 u-6(2012) ; 17$ C.F.R. $\$ 240.21 F-1$ (2012).

63. 15 U.S.C. $\$ 78 \mathrm{u}-6(\mathrm{~h})(2012)$.

64. Id.

65. Id. $\S 78 \mathrm{u}-6(\mathrm{~h})(1)(\mathrm{C})$. 
One of the most notable features of Dodd-Frank is its bounty model, which provides monetary rewards to whistleblowers as an incentive to report. ${ }^{66}$ Under the statute, the SEC is required to pay whistleblowers a minimum of $10 \%$ and a maximum of $30 \%$ of the total monetary sanctions collected in a successful enforcement action resulting from the information that the whistleblower provided. $^{67}$ To qualify for an award, the judicial or administrative action brought on the basis of the whistleblower's information must lead to a sanction exceeding $\$ 1,000,000$ and consist of "original" information. ${ }^{68}$ As discussed earlier, although there is debate as to whether attorney-whistleblowers may receive a bounty under Dodd-Frank, ${ }^{69}$ nothing on the face of the statute bars attorneys from bringing retaliation claims under the statute. $^{70}$

As whistleblowers have started to avail themselves of these robust protections in federal court, case law has been divided on the question of whether internal whistleblowers are guaranteed retaliation protections under Dodd-Frank. The first federal appellate court to rule on this issue was the Fifth Circuit in Asadi v. G.E. Energy, which held that whistleblowers must report externally to the SEC in order to be protected from retaliation under DoddFrank. ${ }^{71}$ The dispute arose from the fact that Asadi, the plaintiff, was an internal whistleblower who reported to his supervisors concerns that G.E. Energy, his employer, was violating the Foreign Corrupt Practices Act. ${ }^{72}$ After reporting, Asadi experienced unexpected negative performance reviews and was eventually terminated, prompting him to sue G.E. Energy under Dodd-

66. $\quad I d . \S 78 \mathrm{u}-6(\mathrm{~b})$.

$67 \quad I d . \$ 78 \mathrm{u}-6(\mathrm{~b}),(\mathrm{c})$.

68. Id. $\S 78 \mathrm{u}-6(\mathrm{a})$, (b). Dodd-Frank defines "original information" as that which is (i) derived from independent knowledge or independent analysis; (ii) not already known to the SEC from another source; and (iii) not exclusively derived from an allegation made in a judicial or administrative hearing or governmental report or investigation.

69. See supra note 19.

70. See 15 U.S.C. $\$ 78 \mathrm{u}-6(\mathrm{a})(6)$, (h) (2012); Greg Keating et al., supra note 18, at 2.

71. 720 F.3d 620 (5th Cir. 2013). For a discussion of the implications of this case on whistleblowers and internal compliance programs, see Pacella, supra note 16 . As will be further discussed, several district courts have since disagreed with Asadi, either finding that Chevron deference to the SEC rules was warranted or that the language itself protects internal whistleblowers. See, e.g., Somers v. Dig. Realty Tr., Inc., No. C-14-5180 EMC, 2015 WL 4483955 (N.D. Cal. July 22, 2015), leave to appeal granted, No. 15-80136 (9th Cir. Oct. 23, 2015); Bussing v. COR Clearing, LLC, 20 F. Supp. 3d 719, 729 (D. Neb. 2014); Yang v. Navigators Grp., Inc., 18 F. Supp. 3d 519, 534 (S.D.N.Y. 2014); Khazin v. TD Ameritrade Holding Corp., No. 13-4149 (SDW) (MCA), 2014 WL 940703, at *6 (D.N.J. Mar. 11, 2014), aff'd on other grounds, 773 F.3d 488, 490 (3d Cir. 2014); Rosenblum v. Thomson Reuters (Markets) LLC, 984 F. Supp. 2d 141, 147-48 (S.D.N.Y. 2013); Ellington v. Giacoumakis, 977 F. Supp. 2d 42, 45 (D. Mass. 2013). In the months before this Article went to print, the Northern District of California reached a notable decision in finding that general counsel for a company who internally blew the whistle is entitled to protection under Dodd-Frank and that board members may be held individually liable for retaliating against whistleblowers. In this case, the court granted Chevron deference to the SEC's reasonable pro-whistleblower construction of the statute. Wadler v. Bio-Rad Labs., Inc., No. 15-CV-02356-JCS, 2015 WL 6438670, at *17 (N.D. Cal. Oct. 23, 2015).

\section{Asadi, 720 F.3d at 621 .}


Frank. ${ }^{73}$ G.E. Energy moved to dismiss on the basis that Asadi did not fit the statutory definition of a "whistleblower"-defined as "any individual who provides, or 2 or more individuals acting jointly who provide, information relating to a violation of the securities laws to the [SEC], in a manner established, by rule or regulation, by the $[\mathrm{SEC}] .{ }^{, 74}$ Asadi argued that this language is in conflict with the third prong of 15 U.S.C. $\$ 78 \mathrm{u}-6$ of DoddFrank, which protects disclosures made by "whistleblowers" that "are required or protected under the Sarbanes-Oxley Act of 2002." "75 Under SOX, employees of publicly-traded companies who blow the whistle on reasonably believed violations of the federal securities laws by their employers are protected from retaliation if they report such information either externally to a federal regulatory or law enforcement agency or to a member or committee of Congress, or internally to anyone with supervisory authority over the employee. $^{76}$

Given that SOX explicitly protects internal reporting, the most natural reading of Dodd-Frank is that the statute is ambiguous in light of the more limiting definition of "whistleblower." Such ambiguity would have prompted Chevron deference to the SEC's reasonable interpretation of the statute. ${ }^{77}$ The SEC had provided a reasonable interpretation of the statute in its final rules implementing the Dodd-Frank whistleblower program, which noted that the third category of whistleblowers protected in subsection (h) "includes individuals who report to persons or governmental authorities other than the Commission" by incorporating by reference the anti-retaliation protections specified in SOX. ${ }^{78}$ Instead, the Fifth Circuit held that the language of the statute was unambiguous on its face because a whistleblower is defined as someone who reports to the SEC, thereby barring the internal whistleblower from relief. ${ }^{79}$

Some commentators and courts have reacted with opposition to the Fifth Circuit's decision in Asadi, which strayed from a string of pro-internal

73. Id.

74. See id.; 15 U.S.C. § 78u-6(a)(6) (2012).

75. Asadi, 720 F.3d at 624 .

76. 18 U.S.C. $\$ 1514 \mathrm{~A}(\mathrm{a})(2012)$.

77. Pacella, supra note 16, at 747. Chevron deference is necessary in questions of statutory interpretation and involves two steps. Chevron U.S.A. Inc. v. Nat. Res. Def. Council, Inc., 467 U.S. 837 (1984). First, the court must ask whether Congress has directly spoken to the precise question at issue. If so, it must give effect to the "unambiguously expressed intent of Congress." If, instead, the court determines that the language of the statute is ambiguous, then it must give deference to the administrative agency's permissible construction of the statute. Id. at 842-43.

78. Securities Whistleblower Incentives and Protections, 76 Fed. Reg. 34,300-01, 34,304 (June 13, 2011) (codified at 17 C.F.R. pts. 240-249). SOX protects whistleblowers who report information to "(A) a Federal regulatory or law enforcement agency; (B) any Member of Congress or any committee of Congress; or (C) a person with supervisory authority over the employee (or such other person working for the employer who has the authority to investigate, discover, or terminate misconduct)." 18 U.S.C. § 1514A (2012).

79. Asadi, 720 F.3d at $625-27$. 
whistleblower cases that had preceded the decision. ${ }^{80}$ Recently, the Second Circuit weighed in on the issue in Berman v. Neo@Ogilvy LLC. ${ }^{81}$ Finding that the "tension" between the statutory definition of "whistleblower" and the protections enumerated in the third prong of 15 U.S.C. $\$ 78 \mathrm{u}-6(\mathrm{~h})$ of DoddFrank are ambiguous enough to warrant Chevron deference, the Second Circuit created a circuit split. ${ }^{82}$ In coming to this decision, the court noted the lack of legislative history behind the insertion of the third prong of 15 U.S.C. $\$ 78 \mathrm{u}-$ $6(\mathrm{~h})$ in the statute. An earlier version that had passed the House and Senate had not included this language. ${ }^{83}$ The Second Circuit further supported its finding of ambiguity by discussing the "realities of the legislative process" and that "it is not at all surprising that no one noticed" that the later insertion of the third prong of protections, which incorporates by reference disclosures under SOX, did not fit squarely with the definition of "whistleblower." 84 As such, the decision grants Chevron deference to the SEC's reasonable and whistleblowerfriendly interpretation of the statute.

Despite the Second Circuit's persuasive reasoning, several courts in subsequent decisions have followed Asadi, finding that the language of DoddFrank is clear enough on its face to require whistleblowers to report to the SEC to be eligible for protections. ${ }^{85}$ Given the current division among the courts, it is likely that the Supreme Court will eventually address this issue. ${ }^{86}$ Until then, and depending on how future courts tackle this issue in light of their statutory interpretations or geographic region, though attorneys are mandated by the Part 205 Rules to report internally, it is currently not guaranteed that they will be able to avail themselves of the robust retaliation protections under Dodd-Frank. By making an external report to the SEC, as the definition of "whistleblower"

80. See Pacella, supra note 16, at 733-41. Each of these cases involved whistleblowers, none of which were attorneys, who reported internally.

81. Berman v. Neo@Ogilvy LLC, 801 F.3d 145 (2d Cir. 2015).

82. Id. at 153 .

83. Id. at 152 .

84. Id. at 154. The Second Circuit also discussed that Asadi's interpretation of the statute would limit retaliation protections for auditors and attorneys subject to internal reporting requirements under SOX. Id. at 151.

85. See, e.g., Verfuerth v. Orion Energy Sys., Inc., 65 F. Supp. 640, 643-46 (E.D. Wis. 2014); Banko v. Apple Inc., 20 F. Supp. 3d 749, 756-57 (N.D. Cal. 2013); Wagner v. Bank of Am. Corp., No. 12-cv-00381-RBJ, 2013 WL 3786643, at*4-6 (D. Colo. July 19, 2013).

86. Shortly after the Second Circuit's decision, defendant, Neo@Ogilvy LLC planned to petition the Supreme Court to address this circuit split. See Matthew Bultman, Neo@Ogilvy to Seek High Court Review In Whistleblower Case, LAw360 (Oct. 1, 2015), http:/www.law360.com/articles/709871/neo-ogilvy-to-seek-high-court-review-in-whistleblower-case. However, on November 10, 2015, Neo@Ogilvy LLC announced that they would not be moving forward with a writ of certiorari with the Supreme Court. Thus, this circuit split remains. See Whistleblower Developments in Courts and Agencies, 255 N.Y. L.J. (Feb. 5, 2016), http:/www.skadden.com/sites/default/files/publications/Whistleblower_Developments_In_Courts_and Agencies.pdf. 
in the statute would require, attorneys may subject themselves to an ethical dilemma by breaching the duty of confidentiality. 87

This problem will be addressed fully in Part III. To avoid such a dilemma, attorneys may also turn to state and other statutory law offering retaliation protections. However, as will be discussed in the next section, the protections afforded under these sources provide relatively weak remedies and have largely proven ineffective in protecting whistleblowers.

\section{Weaknesses of Other Retaliation Protections for Attorney-Whistleblowers}

\section{A. State Law Protections for Retaliatory Discharge}

If attorney-whistleblowers must rely on state law retaliation protections because of the current uncertainty as to whether Dodd-Frank will protect internal reporting, they are likely to face many roadblocks given the inconsistency of such protections. Prior to the advent of statutory protections for whistleblowers, attorneys, like other employees, had to rely on the common law state tort claim of retaliatory discharge. Under this cause of action, an employee who is terminated for engaging in certain actions protected by public policy, such as complaining about an employer's unlawful behavior or blowing the whistle, is eligible for relief. ${ }^{88}$ This right to sue is considered an exception to the common law employment-at-will doctrine and, although it may differ depending on the jurisdiction, it generally protects employees from being fired for exercising statutory or constitutional rights, "for refusing to violate the law ... or for reporting their employer's wrongdoing." ${ }^{89}$ This doctrine is not a perfect remedy for attorney-whistleblowers, as it creates a tension between "the conception of inside counsel primarily as an employee, deserving some judicial protection from retaliation, and as a lawyer-advocate, whose client has an unfettered right to terminate [their lawyer]."

87. This Article, specifically Part III, will focus mainly on the implications of such disclosures on breaching the duty of confidentiality, which is much broader than the confines of the attorney-client privilege. See Kathleen Clark, Government Lawyers and Confidentiality Norms, 85 WASH. U. L. REV. 1033, 1041-44 (2007) (discussing that the evidentiary rule of attorney-client privilege is sometimes conflated with the professional rule of a lawyer's duty of confidentiality. As Clark clarifies, the duty of confidentiality is more extensive in that it applies to all communications between the lawyer and client, whereas " $[t]$ he attorney-client privilege, by contrast, is an evidentiary privilege. . . [that] prevents the state from requiring the disclosure of certain communications between a lawyer and client regarding legal representation. . . [and is] narrow in scope and covers only those communications between a lawyer and client that were made in confidence and for the purposes of providing or obtaining legal advice." (citing RESTATEMENT THIRD OF THE LAW GOVERNING LAWYERS § 68 (2000))). Whenever this Article intends to refer to the more limited "attorney-client privilege," that specific term will be used.

88. Brandon v. Anesthesia \& Pain Mgmt. Assocs., Ltd., 277 F.3d 936, 940-41 (7th

Cir. 2002).

89. Corello, supra note 55, at 391-96 (citing Petermann v. Int'l Bhd. of Teamsters Local, 344 P.2d 25 (Cal. Dist. Ct. App. 1959) as the first case to recognize this exception).

90. Kim, supra note 57, at 1064. 
Early courts typically denied inside counsel this right to sue. Perhaps one of the best-known cases denying counsel retaliation rights is Balla v. Gambro, which barred an in-house attorney from bringing a retaliatory discharge claim against his former employer after he was fired for refusing to support his employer's decision to sell "misbranded and/or adulterated" kidney dialyzers. ${ }^{91}$ The court acknowledged that, although the attorney had a mandatory ethical duty to reveal information to the extent necessary to prevent a client from committing an act likely to result in serious bodily injury or death, he could not then avail himself of relief under the tort of retaliatory discharge due to the "chilling effect" such an action would have on the sanctity of the attorney/client relationship." 92 Decisions like Balla were based on the notion that attorneys must sometimes "sacrifice" their livelihood and employment for the purpose of "protect[ing] the "integrity of the legal profession." 93

Other courts have since relaxed the rigidity of Balla and acknowledged that lawyers should be entitled to the same rights as other employees. These courts have recognized a right to sue for retaliatory discharge in instances where no confidentiality concerns would be at play and, if they are, have permitted the attorney to proceed with the claim provided that he/she safeguards the sensitive information through procedural methods. ${ }^{94}$ They have also acknowledged professional codes of ethics as sources of public policy worthy of supporting a retaliatory discharge claim, thereby protecting in-house lawyers from pressure by their employers to violate the rules of professional conduct by furthering a client's intent to commit a crime or fraud. ${ }^{95}$ In General Dynamics Corporation v. Superior Court, the Supreme Court of California invoked the vulnerability of in-house counsel as completely dependent "on the good will and confidence of a single employer to provide livelihood and career success" to justify the need for retaliation protections for attorneys representing corporations, whose essential goal is to maximize profits. ${ }^{96}$ The court held that in-house lawyers have a well-justified right to redress and that courts handling these matters can institute measures to ensure client confidences are left intact

91. 584 N.E.2d 104, 106 (Ill. 1991).

92. Id. at 109-10. ("Employers might be hesitant to turn to their in-house counsel for advice regarding potentially questionable corporate conduct knowing that their in-house counsel could use this information in a retaliatory discharge suit.").

93. Kim, supra note 57 , at 1065 (citing Balla, 145584 N.E.2d at 110).

94. Id. (citing Gen. Dynamics Corp. v. Superior Ct., 876 P.2d 487, 490 (Cal. 1994)).

95. Corello, supra note 55, at 397-98 ("Employees who are professionals owe a special duty to abide not only by federal and state law, but also by the recognized codes of ethics of their professions. That duty may oblige them to decline to perform acts required by their employers." (citing Pierce v. Ortho Pharm. Corp., 417 A.2d 505, 512 (N.J. 1980))); see also Petermann v. Int'l Bhd. of Teamsters Local, 344 P.2d 25, 27 (Cal. Dist. Ct. App. 1959); In re Meeker, 414 P.2d 862, 864 (N.M. 1966)); Begg, supra note 59, at 209 (discussing professional ethics codes as sources of public policy).

96. General Dynamics, 876 P.2d at 498 . 
when lawyers bring retaliation claims, including the use of sealing and protective orders, limiting admissible evidence, or in camera proceedings. ${ }^{97}$

Though it expanded in-house lawyers' access to retaliation claims, the court in General Dynamics held that, if a claim for retaliatory discharge cannot be established without breaching the attorney-client privilege, then the case must be dismissed to preserve that privilege. ${ }^{98}$ As courts and scholars have noted, it may prove exceedingly difficult for an in-house attorney to establish claims of retaliatory discharge without disclosing some aspect of the privilege. ${ }^{99}$ Although a few cases have permitted in-house counsel to reveal client confidences to the extent reasonably believed necessary to support their retaliatory discharge claims, as Sung Hui Kim notes, many courts have not fully examined the "critical issue" of whether "confidential" or "privileged" information may be used to support such claims and fail to acknowledge the important distinction between these two differing types of classifications. ${ }^{100}$ Another problem in relying on this tort claim is that it is difficult for potential plaintiffs to predict the precise approach a court will take or the outcome it will reach in such cases given the lack of consistency among the states in these decisions. ${ }^{101}$ These difficulties, along with the fact that many courts have simply not recognized the retaliatory discharge claim as being available to lawyers, ${ }^{102}$ have contributed to the need for statutory whistleblower protections for attorney-whistleblowers.

97. Id. at 504. For example, "by taking an aggressive managerial role, judges can minimize the dangers to the legitimate privilege interests" presented by these cases. $I d$.

98. Id. In litigation involving disputes over attorneys' fees, courts have tended to find that the attorney-client privilege is waived by the client by placing the matter in dispute or that the Model Rules offer an exception to the lawyer's duty of confidentiality to resolve a dispute between the lawyer and client. See, e.g., Ideal Elec. Sec. Co. v. Int'l Fid. Ins. Co., 129 F.3d 143, 146 (D.C. Cir. 1997); United States v. Ballard, 779 F.2d 287, 292 (5th Cir. 1986); MODEL Rules of Prof'L CoNDUCT r. 1.6(b)(5) (2003); TRIAL OBJECTIONS HANDBOOK 2d $\S 5: 8$ (2015).

99. See Kim, supra note 57, at 1066 (noting that such difficulties are likely to arise given "the role that inside lawyers play and the nature of the allegations inherent in a retaliatory discharge claim by employed lawyers").

100. Burkhart v. Semitool, Inc., 5 P.3d 1031, 1041 (Mont. 2000); Crews v. Buckman Labs. Int'l Inc., 78 S.W.3d 852, 866 (Tenn. 2002); Spratley v. State Farm Mut. Auto. Ins. Co., 78 P.3d 603, 608 (Utah 2003); Kim, supra note 57, at 1066 (citing Alexander v. Tandem Staffing Sols., Inc., 881 So. 2d 607, 609 (Fla. Dist. Ct. App. 2004)).

101. See Long, supra note 53, at 1076-77 (explaining the variations among courts on these issues).

102. Kim, supra note 57 , at 1066 . Kim also notes that among the courts that have recognized such a cause of action, many have failed to address the issue of whether inside counsel may use privileged or confidential material in pursuing their claims. See Raymis H.C. Kim, In-House Counsel's Wrongful Discharge Action Under the Public Policy Exception and Retaliatory Discharge Doctrine, 67 WASH. L. REV. 893, 894 (1992) (noting that most courts have refused to apply these protections to in-house attorneys due to "the traditional at-will nature of attorney-client employment and the possible adverse effect such causes of action may have on the attorney-client relationship"). 


\section{B. Statutory Protection for Attorney-Whistleblowers}

Retaliation cases brought under whistleblowing statutes have brought more clarity than state law retaliation protections as to whether attorneys may rely on confidential client information to support their retaliation claims. Attorneys have been found eligible for such statutory retaliation protections, including under SOX, and have been permitted to use confidential client information to pursue their cases. The 2005 decision in Willy v. Administrative Review Board was the first to directly address the issue of confidentiality concerns in instances of lawyer-whistleblowers bringing claims under a federal whistleblowing statute that provides retaliation protections. ${ }^{103}$ In this decision, the Fifth Circuit allowed a terminated in-house attorney to pursue a retaliation claim under several environmental statutes for blowing the whistle on his employer's alleged federal environmental violations. ${ }^{104}$ The court found that the confidential information in question was admissible under the "breach of duty" exception to the general non-disclosure rule of client confidences, allowing an attorney to reveal confidences to bring an offensive claim against a client, rather than only as a defense against charges brought by the client against the lawyer. ${ }^{105}$ In coming to this conclusion, the Fifth Circuit relied on precedent from Doe v. A. Corp., which held that an attorney is not barred from pursuing his/her rights against a former client or employer just because proving these rights may involve the use of confidential information. ${ }^{106}$ The decision in Willy is consistent with the position of the American Bar Association, expressed in a formal opinion in 2001, that the Model Rules do not prohibit a lawyer from suing former clients when the lawyer was terminated for complying with his/her ethical obligations. ${ }^{107}$

Cases brought in the years since SOX's enactment reveal that attorneywhistleblowers may avail themselves of SOX's protections. One of the most

103. 423 F.3d 483 (5th Cir. 2005).

104. Id. at 486 .

105. Id. at 495-96. In so deciding, the Fifth Circuit rejected the DOL Administrative Review Board's reliance on the First Circuit's decision in Siedle v. Putnam Investments, Inc. that an attorney may use privileged information only defensively "as a shield and never as a sword." Id. at 496 (citing Siedle, 147 F.3d 7, 11 (1st Cir. 1998)). The breach of duty exception of Supreme Court Standard 503(d) states that there is no attorney/client privilege as it pertains to "a communication relevant to an issue of breach of duty by the lawyer to his client or by the client to the lawyer. .." Id. at 496. Model Rule of Professional Conduct 1.6(b)(5) similarly allows a lawyer to reveal confidential information relating to his/her representation of the client to the extent reasonably necessary to "establish a claim or defense on behalf of the lawyer in a controversy between the lawyer and the client, to establish a defense to a criminal charge or civil claim against the lawyer based upon conduct in which the client was involved, or to respond to allegations in any proceeding concerning the lawyer's representation of the client." MODEL RULES OF PROF'L CONDUCT R. 1.6(b)(5) (2003) (emphasis added).

(5th Cir. 1983)).

106. See Willy, 423 F.3d at 498-499 (citing Doe v. A. Corp., 709 F.2d 1043, 1050

107. ABA Comm. on Ethics \& Prof'1 Responsibility, Formal Op. 01-424 (2001). The ABA also noted that in-house lawyers pursuing such claims must comply with the duty of confidentiality to former clients and may reveal information only to the extent necessary to establish his/her claim against the employer. 
notable of such cases is Van Asdale v. International Game Technology, which allowed two former general counsels to proceed with a retaliation claim after alleging that they were terminated for reporting possible fraud in connection with a merger that their employer/client was undergoing. ${ }^{108}$ When the former employer claimed that the attorneys were barred from bringing forth such claims due to their ethical obligations under the Illinois rules of professional conduct, the Ninth Circuit held that confidentiality concerns alone would not merit dismissal of the case. ${ }^{109}$ Further, the court noted that the "text and structure" of SOX add strength to the ability of the case to proceed, as SOX expressly allows any "person" alleging retaliation to file a complaint before the Secretary of Labor and nothing in the statute's language reveals that an inhouse lawyer is not also protected from retaliation thereunder. ${ }^{10}$ Although attorneys are able to seek relief under SOX for acting as whistleblowers, empirical studies conducted on the success of SOX retaliation claims suggest that the actual probability of success under the statute is low. ${ }^{111}$ Very few internal and external whistleblowers have actually obtained relief under SOX, despite the high hopes of Congress for the statute's success when it was enacted in 2002. ${ }^{112}$

SOX relies on two models to encourage whistleblowing-an "antiretaliation" provision, which provides redress to employees of publicly traded companies who experience retaliation after blowing the whistle, and a "structural model" geared toward changing the then-prevalent corporate culture of staying silent after witnessing misconduct. ${ }^{113}$ Whistleblowers need not report externally to be protected under SOX. ${ }^{114}$ As Terry Dworkin has noted, the SOX

108. 577 F.3d 989 (9th Cir. 2009); see also Jordan v. Sprint Nextel Corp., ARB No. 06-105 (ARB Sept. 30, 2009) (ruling that an in-house attorney may utilize statements covered by the attorney-client privilege in support of a SOX whistleblower claim).

109. Van Asdale, supra note 108, at 995-96.

110. Id. at 996 . In so deciding, the Ninth Circuit also noted that Congress had "plainly considered the role attorneys might play in reporting possible securities fraud" in calling for the Part 205 Rules. Id.

111. See Richard Moberly, Unfulfilled Expectations: An Empirical Analysis of Why Sarbanes-Oxley's Whistleblowers Rarely Win, 49 WM. \& MARY L. REV. 65 (2007) (examining the lack of success of SOX whistleblowing claims); see also Beverley H. Earle \& Gerald A. Madek, The Mirage of Whistleblower Protection Under Sarbanes-Oxley: A Proposal for Change, 44 AM. BuS. L.J. 1 (2007) (proposing changes to SOX to better protect whistleblowers).

112. Richard Moberly, Sarbanes-Oxley's Whistleblower Provisions: Ten Years Later, 64 S.C. L. REV. 1, 10 (2012) [hereinafter Moberly, Ten Years Later] (citing scholars and advocates who opined that "Sarbanes-Oxley greatly improved whistleblower protections in the United States"). Prior to SOX, corporate whistleblowers reporting fraud and thereafter experiencing retaliation could turn only to a "patchwork" of various state laws, resulting in dramatic variations among states and making it difficult for employees to predict the scope of their protection. Id. at 7 (noting that no statute prior to SOX addressed "far-reaching misconduct such as the fraud that led to Enron-like scandals"); see also S. REP. No. 107-146, at 10 (2002) (discussing SOX's need to address the problem that whistleblowers were "left unprotected under current law").

113. Moberly, Ten Years Later, supra note 112, at 10; see also Richard Moberly, Sarbanes-Oxley's Structural Model to Encourage Corporate Whistleblowers, 2006 BYU L. REV. 1107, 1131 (2006) (discussing these whistleblower models).

$$
\text { 114. } 18 \text { U.S.C. \$ 1514A (2012). }
$$


whistleblower program is thus distinguishable from other state and federal statutes in that it "specif[ies] internal whistleblowing as an appropriate channel," thereby "following common whistleblower practice" given that most whistleblowers tend to initially report internally. ${ }^{115}$

In order to file a claim under SOX, the whistleblower must undergo several cumbersome administrative hurdles. First, the procedural requirements of SOX's implementing regulations require an aggrieved whistleblower to file a complaint with the Occupational Safety and Health Administration (OSHA), which investigates the claim. ${ }^{116}$ If OSHA substantiates the claim, the whistleblower is entitled to remedies, including reinstatement of employment, back pay with interest, and litigation and attorney's fees. ${ }^{117}$ Each party may appeal OSHA's decision to an Administrative Law Judge (ALJ) with a chance for further appeal to the Administrative Review Board and then ultimately to federal court. $^{118}$

Scholars have widely acknowledged the weaknesses in SOX's retaliation protections. ${ }^{119}$ Richard Moberly, who conducted an extensive empirical study of all decisions issued by OSHA and ALJs under SOX, revealed in 2007 that a mere $3.6 \%$ of SOX whistleblowers have obtained relief under the statute and that only $6.5 \%$ won on appeal. ${ }^{120}$ Moberly did a follow-up study in 2012 , which affirmed SOX's weaknesses and found that the success rate for whistleblowers had been even worse since his first study. ${ }^{121}$ The numbers appear to be so low, in part, due to the short statute of limitations of 180 days, "rigorous filtering systems," and "causation hurdles" necessary to prevail in an OSHA investigation or ALJ hearing, specifically the whistleblower's requirement to prove that the protected activity was a contributing factor in the adverse action, at which point the employer has the opportunity to demonstrate by "clear and convincing evidence" that it would have arrived at the same decision without the existence of the protected activity. ${ }^{122}$

115. Terry Morehead Dworkin, SOX and Whistleblowing, 105 MICH. L. REV. 1757, 1760 (2007) (noting that most state and federal whistleblower statutes only designate external reporting as eligible for protection).

116. 18 U.S.C. $\S 1514$ A(b) (2012). OSHA will investigate the claim if the employee has presented a prima facie case showing that the subject of the complaint knew the employee engaged in protected behavior and that the protected activity was "a contributing factor" to the employer's alleged adverse action. 29 C.F.R. $\$ 1980.104$ (b)(2) (2015).

117. 24 C.F.R. $\$ 1980.105$ (2012).

118. 24 C.F.R. $\S \S 1980.107$, 1980.110, 1980.112 (2012); Moberly, Ten Years Later, supra note 112 , at 9 .

119. See, e.g., Dworkin, supra note 115, at 1764-66; Earle \& Madek, supra note 111; Moberly, supra note 111; Moberly, Ten Years Later, supra note 112.

120. Moberly, supra note 111 , at 67 (noting that, by July 13, 2005, OSHA had issued 361 SOX decisions and only 19 claimants won).

121. Moberly, Ten Years Later, supra note 112, at 28-35.

122. 29 C.F.R. $§ 1980.104$ (e) (2009); Moberly, supra note 111, at 100-06. Prior to amendments made to SOX by Dodd-Frank in 2010, SOX's statute of limitations was even shorter, at a mere 90 days. See Moberly, Ten Years Later, supra note 112, at 16. 
In approximately $34 \%$ of the ALJ cases and $19 \%$ of the OSHA cases finding in favor of the employer, the reason was due to failure to meet the statute of limitations, as administrators generally refused requests for equitable tolling. ${ }^{123}$ Beverley Earle and Gerald Madek have also found several weaknesses in SOX's whistleblower protections, specifically the short statute of limitations and OSHA enforcement of SOX's whistleblower provisions, which they argue may be more efficiently handled by the SEC, as the agency specialized in the underlying substance. ${ }^{124}$

One of the most significant findings of Moberly's study is that many whistleblowers were excluded from SOX's protections because the type of fraud or misconduct that they reported was not one of the categories of "protected activity" listed in the statute. SOX only protects whistleblowers who disclose conduct that they reasonably believe would be a violation of one or more of six specific categories-(i) mail fraud, (ii) wire fraud, (iii) banking fraud, (iv) securities fraud, (v) any SEC rule or regulation, or (vi) any provision of federal law that relates to fraud against shareholders. ${ }^{125}$ Along with the other weaknesses of SOX, it is this likelihood of statutory exclusion that places attorney-whistleblowers who experience retaliation in a position in which they will be unlikely to avail themselves of the statute's protections.

As Moberly's study reveals, employees alleged that they blew the whistle on "general fraud" or accounting irregularities at a much higher rate than on the types of misconduct enumerated in the statute. Specifically, at least $48 \%$ of whistleblowers bringing claims before OSHA and 52.7\% before ALJs asserted the disclosure of "other" fraud activity that was not specifically listed in any of the six categories under SOX. ${ }^{126}$ In cases where OSHA and ALJs did not decide in favor of the employee-whistleblower based on the rationale that their disclosure constituted "no protected activity," employees had alleged protected activity in the "other" category in $78.9 \%$ and $75 \%$ of the cases decided by OSHA and ALJs, respectively. ${ }^{127}$ A qualitative examination of such cases reveals that ALJs tended to interpret the language of SOX "narrowly,"

123. Moberly, supra note 111, at 107-09. Moberly's study reveals that OSHA and ALJs both regularly "rebuffed" whistleblower claims that the statute of limitations should be tolled for equitable reasons, deciding to toll the statute of limitations in only one case in which the whistleblower missed the deadline by two days. $I d$.

124. Earle \& Madek, supra note 111, at 3, 51-54.

125. 18 U.S.C. $\$ 1514$ A (2012) (the language of SOX references the various statutory citations of these types of fraud, which, for i, ii, iii, and iv. listed above are 18 U.S.C. $\S \S 1341,1343$, 1344 , or 1348, respectively); Moberly, supra note 111 , at 113 .

126. Moberly, supra note 111, at 116-18. In cases involving "accounting fraud," employees were found not to have engaged in "protected activity" due to an inability to tie accounting irregularities "directly to active fraud on the shareholders" or a "broader scheme of intentional corporate fraud."

127 Id. at 116-17 ("[E]mployee[s] alleged blowing the whistle on illegal activity falling within the 'other' category and the 'fraud' category more frequently in cases in which the decision maker utilized the 'no protected activity' rationale than in the overall pool of cases."). 
requiring whistleblowers to directly connect their disclosures of misconduct to shareholder fraud - a line that was mostly quite difficult to draw. ${ }^{128}$

One important consideration is that attorneys appearing and practicing before the SEC who are mandated to be internal whistleblowers are likely to have similar difficulty arguing that their disclosures fall within one of the specific categories of protected activity under SOX given the very broad nature of those reporting requirements. Under the mandatory reporting obligations of the Part 205 Rules, attorneys are required to report "evidence of a material violation" of which they become aware by the issuer-client or any of its constituents (officers, directors, employees, or agents). ${ }^{129}$ The Part 205 Rules define the attorney's reporting trigger, "material violation," as "an applicable United States federal or state securities law, a material breach of fiduciary duty arising under United States federal or state law, or a similar material violation of any United States federal or state law." 130 As might be surprising, attorneys are also required to report on breaches of fiduciary duties, which are defined as breaches of fiduciary or similar duties recognized under federal, state, or common law, "including but not limited to misfeasance, nonfeasance, abdication of duty, abuse of trust, and approval of unlawful transactions."

These internal reporting requirements are broader than the six categories of the SOX whistleblower program's protected activity. In fact, even before the finalization of the Part 205 Rules, public comments during the SEC's rulemaking process voiced these concerns. One group of attorneys expressed that the Part 205 Rules were both "unworkable and inappropriate," creating an "extraordinary level of ambiguity" for lawyers. ${ }^{132}$ By encompassing various violations of both federal and state law not limited to securities law, one scholar noted that "Congress and the SEC appear to have meant to paint with a broad brush." 133 Given the limitations of SOX's whistleblowing program, Congress enacted the Dodd-Frank whistleblower program in 2010 in an effort to more

128. Id. at 117-18. Moberly offers the examples of Grant v. Dominion East Ohio Gas, 2004-SOX-63, at 40 (ALJ Mar. 10, 2005), in which the ALJ found that an employee who reported accounting errors had not engaged in "protected activity" because of the employee's inability to "tie these irregularities directly to active fraud on the shareholders," and Allen v. Stewart Enterprises, Inc. 2004-SOX-60, at 83-84 (ALJ Feb. 15, 2005), in which employees internally reported instances of erroneous interest calculations, untimely refunds, and improper accounting practices but could not demonstrate that such errors were related to a broader scheme of fraud, thereby resulting in the ALJ's refusal to find that "protected activity" had occurred.

129. 17 C.F.R. $\$ 205.3$ (b) (2015).

130 Id. $\$ 205.2(i)$. The SEC defines "evidence of a material violation" as follows: "credible evidence, based upon which it would be unreasonable, under the circumstances, for a prudent and competent attorney not to conclude that it is reasonably likely that a material violation has occurred, is ongoing, or is about to occur." Id. $\S 205.2(\mathrm{e})$.

131. Id. $\S 205.2(\mathrm{~d})$.

132. Letter from Akin Gump Strauss Hauer \& Feld L.L.P. et al., to Jonathan G. Katz, Sec'y, Sec. \& Exch. Comm'n, 2002 WL 32849177 (Dec. 18, 2002).

133 Larry Catá Backer, Surveillance and Control: Privatizing and Nationalizing Corporate Monitoring After Sarbanes-Oxley, 2004 MicH. ST. L. REv. 327, 379 (2004) (noting that the "literal language" of the reporting regulations "suggests a broad scope of reportable activity"). 
strongly incentivize whistleblowers to report and to remedy the inadequacies of SOX. ${ }^{134}$ Although the body of case law interpreting Dodd-Frank is still evolving, the statute is very likely to result in more success for whistleblowers, especially given its removal of significant procedural and administrative burdens, its expansion of statutory protected activity, and its longer statute of limitations. ${ }^{135}$ One source has compiled statistics that already suggest higher reliance on Dodd-Frank by whistleblower-plaintiffs- "[from the law's enactment in July 2010 through July 21, 2015], 56 reported federal retaliation cases have cited at least one of the whistleblower provisions Dodd-Frank created. [During that period], there have been about 200 reported decisions more than a 50 percent increase from the preceding five-year period." "136 Despite prospects of a higher level of success, it remains to be seen whether Dodd-Frank provides protections to internal whistleblowers. ${ }^{137}$ If the Fifth Circuit view prevails, the only way attorney-whistleblowers could avail themselves of these protections is if they report externally-an action giving rise to an ethical dilemma depending on the jurisdiction in which the attorney is admitted to practice.

\section{Conflicting Regulatory Regimes Governing Attorney Reporting}

\section{A. ABA's 2003 Amendments to the Model Rules}

If attorneys must report externally to be protected by the strong retaliation protections available under Dodd-Frank, they may, at the same time, violate their ethical duty of confidentiality if admitted in a jurisdiction that does not permit the same type of reporting. The relationship of trust between an individual client and a lawyer ${ }^{138}$ has long been heralded as sacrosanct. ${ }^{139}$ The Model Rules of Professional Conduct of the American Bar Association (ABA) highlight these principles, noting that one of the most fundamental aspects of

134. See, e.g., Bishara, Callahan \& Dworkin, supra note 36, at 49 (noting that the "perceived inadequacies" of SOX "contributed to the passage of the Dodd-Frank Act in 2010"); Pauline T. Kim, Electronic Privacy and Employee Speech, 87 CHI.-KENT L. REV. 901, 925 (2012) (noting that the Dodd-Frank whistleblower program strengthens and expands the coverage of SOX's anti-retaliation provisions by "addressing some of its perceived shortcomings").

135. Dallas Hammer \& Jason Zuckerman, Taking Stock of the Success of DoddFrank's Whistleblower Provisions, Gov'T ACCOUNTABILITY PROJECT (July 21, 2015), https://www.whistleblower.org/blog/125021-taking-stock-success-dodd-frank's-whistleblowerprovisions.

136. Id.

137. See supra Part I.B.

138. Kim, supra note 35 , at 115 (discussing the differences between a lawyer's duty to keep secrets in the "individual human client" context and that involving corporate clients, as the duty under the latter is "severely qualified").

139. "There are few of the business relations of life involving a higher trust and confidence than that of attorney and client, or, generally speaking, one more honorably and faithfully discharged..." Stockton v. Ford, 52 U.S. 232, 247 (1850). These principles are often cited in the present-day. See, e.g., McClure v. Thompson, 323 F.3d 1233, 1242 (9th Cir. 2003). 
the attorney-client relationship is the lawyer's duty of confidentiality. ${ }^{140}$ Under Model Rule 1.6, lawyers may not reveal information "relating to the representation of a client" unless the client consents or, in the event of other limited circumstances, including, for example, to prevent reasonably certain death or substantial bodily harm or a crime or fraud reasonably certain to create substantial, financial, or proprietary injury to another. ${ }^{141}$ Beyond the exceptions set forth in Rule 1.6, Model Rule 1.13 allows the attorney who represents an organization to reveal confidential client information in certain instances that are discussed below. ${ }^{142}$

The ABA amended Model Rules 1.6 and 1.13 in 2003 to follow the SEC's Part 205 Rules; some believed these amendments were an effort to retain control over the regulation of attorneys at a time when the federal government seemed to encroach on this area. ${ }^{143}$ The current Model Rule 1.13 requires an attorney to report up the ladder to the "highest authority" of the organizationusually the board of directors - any knowledge that he/she has that an officer, employee, or other person within the organization is violating the law or a legal obligation to the organization in a manner that is likely to result in substantial injury to it. ${ }^{144}$ Model Rule 1.13 also allows an attorney to reveal confidential information externally, whether or not Rule 1.6 would so allow, if the highest authority "insists upon" or "fails to address in a timely and appropriate manner" the violation of the law and the attorney "reasonably believes that the violation is reasonably certain to result in substantial injury to the organization."145

The ABA's 2003 amendments to the Model Rules recognize that "a prudent corporate governance program should call upon lawyers - notably the corporation's general counsel-to assist in the design and maintenance of the corporations' procedures for promoting legal compliance."146 As such, the ABA amended the exceptions to the duty of confidentiality and the duties of

140. See MOdel RUles OF PROF'L CONDUCT r. 1.6 and cmt 2; see also David B. Wilkins, Do Clients Have Ethical Obligations to Lawyers? Some Lessons from the Diversity Wars, 11 GEO. J. LEGAL ETHICS 855, 889 (1998) (noting that the lawyer's most important ethical duties are the duties of confidentiality and loyalty, which "are justified on the ground that they are essential for fostering the level of trust necessary for clients to allow lawyers access to sensitive information and control over a client's legal affairs").

141. MOdel Rules of PROF'L CONDUCT r. 1.6 (2003).

142. Id. r. 1.13 .

143. Id. r. 1.6, r. 1.13; 2003 Amendments, A.B.A. (Aug. 11-12, 2003), http:/www.americanbar.org/content/dam/aba/migrated/leadership/2003/journal/119c.authcheckdam.pdf [hereinafter ABA Amendments]; see John S. Dzienkowski, Ethical Decisionmaking and the Design of Rules of Ethics, 42 HOFSTRA L. REV. 55, 92 (2013) (noting that the ABA made its 2003 amendments when it was "faced with losing complete control over regulating the disclosure duties of corporate lawyers, [and] chose to make changes that were likely to forestall more aggressive SEC action").

144. MODEL RULES OF PROF'L CONDUCT r. 1.13(b) (2003).

145. Id. r. $1.13(\mathrm{c})$.

146. See ABA Amendments, supra note 143, at 11; see also Theodore Sonde \& F. Ryan Keith, "Up the Ladder" and Over: Regulating Securities Lawyers-Past, Present \& Future, 60 WASH. \& LEE L. REV. 331, 348 (2003) (discussing the findings of the ABA task force that set out to examine existing laws, regulations, and ethical duties governing the role of lawyers). 
lawyers when they represent corporate organizations as clients. The ABA also amended Model Rule 1.6(b) to adopt the current language, which allows lawyers to reveal confidential information "to prevent the client from committing a crime or fraud that is reasonably certain to result in substantial injury to the financial interests or property of another." ${ }^{147}$ The amendments to Rule 1.6 brought the ABA Model Rules in line with what was already adopted by forty-two states, while the changes to Rule 1.13 were intended to mimic the Part 205 Rules. ${ }^{148}$

Since a lawyer employed or retained by an organization represents the organization itself, "acting through its duly authorized constituents," 149 the mandatory up-the-ladder reporting requirements of both the Part 205 Rules and Model Rule 1.13 should be non-controversial, as all confidential information remains within the confines of the organization itself. ${ }^{150}$ As discussed, attorneys are subject to civil penalties, censure, or temporary or permanent denial of the ability to appear or practice before the SEC if they violate these rules, ${ }^{151}$ "regardless of whether the attorney may also be subject to discipline for the same conduct in a jurisdiction where the attorney is admitted or practices."152 Attorneys appearing and practicing before the SEC may also reveal confidential client information to the agency to the extent they reasonably believe necessary to prevent substantial financial injury to the issuer or investors, to prevent the issuer from committing perjury, or to rectify the consequences of material violations by the issuer in furtherance of which the lawyer's services were used. ${ }^{153}$ It is the inconsistency between this permissive "reporting out" option of the Part 205 Rules and conflicting state ethical rules that imposes an inconsistent regulatory structure upon attorneys who may be subject to both.

147. Model Rules of Prof'L Conduct r. 1.6 (2003); see Clifton Barnes, $A B A$, States, and SEC Hash Out Lawyers' Responsibility in Corporate Settings, 28 B. LEADER 1 (2003), http://www.americanbar.org/publications/bar_leader/2003_04/2802/corporate.html.

148. See Barnes, supra note 147; see also John Paul Lucci, 4th and 205: How a Rush of Global Comments Blocked the SEC's First Attempted Punt of Attorney-Client Privilege Under Sarbanes-Oxley, 20 TOURO L. REV. 363 (2004).

149. MODEL RULES OF PROF'L CONDUCT r. 1.13(a) (2003).

150. This notion is consistent with the beliefs of the SEC and of Congress in enacting Section 307 of SOX. See 17 C.F.R. $\S 205.3$ (b)(1) (2015) (noting that the Part 205 Rules do allow attomeys to "reveal client confidences or secrets or privileged or otherwise protected information related to the attorney's representation of an issuer"); see also 148 CONG. REC. S6524-02 (July 10, 2002) (statement of Sen. Edwards) (dispelling the notion that the mandatory disclosure rules would breach a lawyer's duty of confidentiality as "ludicrous" because the attorney's duty is owed to his/her client, the corporation, and the shareholders-" $[\mathrm{b}] \mathrm{y}$ reporting a legal violation to management and then the board of directors, no breach of privilege occurs, because it is all internal-within the corporation and not to an outside party, such as the SEC").
151. 17 C.F.R. $\$ 205.6(\mathrm{a})$, (b) (2007).
152. Id. $\$ 205.6(\mathrm{~b}),(\mathrm{c})$.
153. Id. $\S 205.3(\mathrm{~d})$. 


\section{B. How State Ethical Rules Compare to the Part 205 Rules and the ABA Model Rules}

Although all states have adopted the mandatory up-the-ladder reporting requirements, ${ }^{154}$ not all have adopted the Part 205 Rules/Model Rule 1.13's permissive disclosure option. Today, thirty-two states have adopted the ABA's Model Rule 1.13, permitting lawyers to report client confidences externally whether or not Rule 1.6 would so allow if they reasonably believe such disclosure is necessary to prevent substantial injury to the organization. ${ }^{155}$ Therefore, lawyers admitted in one of these jurisdictions do not face a conflict. This Section will focus on the ethical rules in the other eighteen states and in Washington, D.C., which have not adopted ABA's Model Rule 1.13, with such states referred to herein as the "Non-Adopting States."156 All states must balance the policy interests in a lawyer's protection of the confidentiality of

\section{See infra Part IV.C.}

155. The following thirty-two states have adopted this rule as of the date of this article: Alaska, Arizona, Arkansas, Colorado, Connecticut, Georgia, Hawaii, Idaho, Illinois, Indiana, Iowa, Kentucky, Louisiana, Maryland, Massachusetts, Michigan, Nebraska, Nevada, New Hampshire, New Jersey, New Mexico, North Dakota, Oklahoma, Oregon, Rhode Island, South Carolina, Utah, Vermont, Washington, West Virginia, Wisconsin, and Wyoming [hereinafter Adopting States]. See ALASKA RULES OF PROF'L CONDUCT r. 1.13(c) (2015-2016); ARIZ. RULES OF PROF'L CONDUCT ER. 1.13(c) (2004); ARK. RULES OF PROF'L CONDUCT r. 1.13(c) (2005); COLO. RULES OF PROF'L CONDUCT r. 1.13(c) (2012); CONN. RULES OF PROF'L CONDUCT r. 1.13(c) (1998); GA. RULES OF PROF'L CONDUCT r. 1.13(c) (2001); Haw. Rules of Prof'L CONDUCT r. 1.13(c) (2013); Idaho Rules OF Prof'L CONDUCT r. 1.13(c) (2014); ILL. RULES OF PROF'L CONDUCT r. 1.13(c) (2009); IND. RULES OF PROF'L CONDUCT r. 1.13(c) (2015); IOWA Rules OF PROF'L CONDUCT r. 32:1.13(c) (2015); Ky. Rules of PROF'L CONDUCT SCR. 3.130(c) (2009); LA. RULES OF PROF'L CONDUCT r. 1.13(c) (2004), MD. RULES OF PROF'L CONDUCT r. 16-812, r 1.13(c) (2005) (external report permitted subject to additional conditions involving conflicted highest authority and acting in best interests of the organization); MAss. RULES OF PROF'L CONDUCT r. 1.13(c) (2016); MiCH. RULES OF PROF'L CONDUCT r. 1.13(c) (2016) (external report permitted subject to additional conditions involving conflicted highest authority and acting in best interests of the organization); NEB. RULES OF PROF'L CONDUCT r. 3-501.13(c) (2008); Nev. Rules of PROF'L CONDUCT r. 1.13(c) (2007); N.H. Rules OF PROF'L CONDUCT r. 1.13(c) (2008); N.J. RULES OF PROF'L CONDUCT r. 1.13(c) (1996) (external report permitted subject to additional conditions involving conflicted highest authority and acting in best interests of the organization); N.M. RULES OF PROF'L CONDUCT r. 16-113(c) (2008); N.D. RULES OF PROF'L CONDUCT r. 1.13(c) (2006); OKLA. Rules OF PROF'L CONDUCT r. 1.13(c) (2007); OR. RULES OF PROF'L CONDUCT r. 1.13(c) (2006); R.I. RULES OF PROF'L CONDUCT r. 1.13(c) (2007); S.C. RULES OF PROF"L CONDUCT r. 1.13(c) (2015); UTAH RULES OF PROF'L CONDUCT r. 1.13(c) (2005); VT. RULES OF PROF'L CONDUCT r. 1.13(c) (2009); WASH. Rules OF Prof'L CONDUCT r. 1.13(c) (2006); W. VA. RULES OF Prof'L CONDUCT r. 1.13(b); Wis. Rules of Prof'L CoNDUCT r. 20:1.13(c) (2013-2014); Wyo. Rules of Prof'L Conduct r. $1.13(\mathrm{c})(1986)$.

156. See Ala. Rules of Prof'L Conduct r. 1.13(c) (2016); Cal. Rules of Prof'L CONDUCT r. 3-600(c) (2015); D.C. Rules OF PROF'L CONDUCT r. 1.13(b) (2007); Del. Rules OF PROF'L CONDUCT r. 1.13(c) (2010); FLA. RULES OF PROF'L CONDUCT r. 4-1.13(c) (2006); KAN. RULES OF PROF'L CONDUCT r. 1.13(c) (2007); ME. RULES OF PROF'L CONDUCT r. 1.13(c) (2013); MINN. RULES OF PROF'L CONDUCT r. 1.13(c) (2015); Miss. Rules of PROF'L CONDUCT r. 1.13(c) (2016); Mo. Rules of Prof"L Conduct r. 4-1.13(c) (2007); Mont. Rules of Prof'L ConduCT r. 1.13(c) (2004); N.Y. RULES OF PROF'L CONDUCT r. 1.13(c) (2014); N.C. RULES OF PROF'L CONDUCT r. 1.13(c) (2006); OHIO RULES OF PROF'L CONDUCT r. 1.13(c) (2016); PA. RULES OF PROF'L CONDUCT r. 1.13(c) (2005); S.D. RULES OF PROF'L CONDUCT r. 1.13(c) (2004); TENN. RULES OF PROF'L CONDUCT r. 1.13(c) (2015); Tex. Disciplinary Rules of Prof'L CONduCt r. 1.12(c) (1995); Va. Rules of Prof'l CONDUCt $r$. 1.13 (c) (2004). 
client information with those of disclosing such information to prevent or mitigate financial or other harm that follows when a client commits wrongdoing - the Non-Adopting States' current rules convey that these states have placed more weight on the preservation of client confidentiality in broad instances. ${ }^{157}$ Interestingly, many of these Non-Adopting States are heavily populated and also likely to contain lawyers working in financial or securitiesrelated arenas who may invoke the whistleblower provisions at play. In fact, the most recent annual report to Congress by the SEC of the Dodd-Frank Whistleblower Program reveals that the highest number of whistleblower tips in fiscal year 2015 came from California, New York, Texas, Florida, and New Jersey ${ }^{158}$-all jurisdictions, with the exception of New Jersey, constituting Non-Adopting States.

In the states of Alabama, California, Delaware, Florida, Kansas, Mississippi, Missouri, Montana, Pennsylvania, South Dakota, and Virginia, an attorney representing an organization who has reported violations up the ladder to the board of directors only to find that the board insists upon the violation or refuses to remediate it has only the option of resigning from representation. ${ }^{159}$ In Maine, Minnesota, New York, North Carolina, Ohio, Tennessee, Texas, and Washington, D.C., an attorney in this same circumstance has the options of either resigning or reporting externally only if permitted by that state's Rule 1.6 (duty of confidentiality). ${ }^{160}$ As the chart reveals below, there are numerous nuances as to whether attorneys may permissively disclose through reliance on Rule 1.6 and several inconsistencies among the states in this regard.

157. See McLucas et al., supra note 18 (explaining the "scope of exceptions [of the duty of confidentiality] among the states as a reflect[ion of] different weighting of each of these competing interests").

158. 2015 Annual Report to Congress on the Dodd-Frank Whistleblower Program, U.S. SEC. \& EXCH. COMM'N 23 (2015), https://www.sec.gov/whistleblower/reportspubs/annualreports/owb-annual-report-2015.pdf. This information reflects general whistleblower tips.

159. See Ala. Rules of Prof'L CONDUCT r. 1.13(c) (2016); Cal. Rules of Prof'L Conduct r. 3-600(c) (2015); Del. Rules of Prof'L ConduCt r. 1.13(c) (2010); Fla. Rules of PROF'L ConduCT r. 4-1.13(c) (2006); KAN. Rules OF Prof'L CONDUCT r. 1.13(c) (2007); Miss. Rules OF PRof'L CONDUCT r. 1.13(c) (2016); Mo. Rules of PROF'L CONDUCT r. 4-1.13(c) (2007); MONT. Rules of PROF'L CONDUCT r. 1.13(c) (2004); PA. RULES OF PROF'L CONDUCT r. 1.13(c) (2005); S.D. Rules of PRof'l CONDUCT r. 1.13(c) (2004); VA. Rules of Prof'L CONDUCT r. 1.13(c) (2004); and accompanying comments to these rules.

160. See D.C. Rules of Prof'L CONDUCT r. 1.13(B) \& cmt.7 (2007); ME. Rules of PROF'L CONDUCT r. 1.13(c) (2013); MinN. Rules of PROF'L CONDUCT r. 1.13 (c) (2015); N.Y. RULES OF PRof'L CONDUCT r. 1.13(c) (2014); N.C. Rules OF PROF'L CONDUCT. 1.13(c) (2006); OHIO. RuLES OF PROF'L CONDUCT r. 1.13(c) (2016); TENN. Rules of PROF'L CONDUCT r. 1.13(c) (2015); TEX. DisCIPLINARY RULES OF PROF'L CONDUCT r. 1.12(c) \& cmt.8 (1995); and accompanying comments to these rules. 
Table 1: Permissive Disclosure Rules of the Non-Adopting States ${ }^{161}$

\begin{tabular}{|c|c|c|c|}
\hline State & $\begin{array}{l}\text { Rule } 1.13 \text { (or } \\
\text { equivalent of } \\
\text { Organization } \\
\text { as Client rule): } \\
\text { Is resignation } \\
\text { the only option } \\
\text { after lawyer } \\
\text { exhausts } \\
\text { internal } \\
\text { reporting? }\end{array}$ & $\begin{array}{l}\text { Rule } 1.6 \text { (or } \\
\text { equivalent of Duty } \\
\text { of Confidentiality } \\
\text { rule and } \\
\text { exceptions): } \\
\text { Is there an } \\
\text { exception to duty } \\
\text { of confidentiality } \\
\text { allowing lawyer to } \\
\text { reveal confidential } \\
\text { information to } \\
\text { prevent client } \\
\text { from committing a } \\
\text { fraud? }\end{array}$ & $\begin{array}{l}\text { Rule } 1.6 \text { (or } \\
\text { equivalent of Duty } \\
\text { of Confidentiality } \\
\text { rule } \\
\text { exceptions): } \\
\text { Is there and } \\
\text { exception to duty } \\
\text { of confidentiality } \\
\text { allowing lawyer to } \\
\text { reveal confidential } \\
\text { information to } \\
\text { prevent client from } \\
\text { committing a } \\
\text { crime likely to } \\
\text { result in substantial } \\
\text { financial injury to } \\
\text { the organization or } \\
\text { another? }\end{array}$ \\
\hline Ala & Yes & No & $\begin{array}{l}\text { No (only to } \\
\text { prevent imminent } \\
\text { death or substantial } \\
\text { bodily harm) }\end{array}$ \\
\hline Californi & Yes & No & $\begin{array}{l}\text { No (only to } \\
\text { prevent death or } \\
\text { substantial bodily } \\
\text { harm) }\end{array}$ \\
\hline Delaware & Yes & Yes (but & Yes \\
\hline
\end{tabular}

161. See supra notes $155-56$ for Organization as Client ethical rules. For Duty of Confidentiality ethical rules and exceptions thereto, see ALA. RULES OF PROF'L CONDUCT r. 1.6(b) (2016); CAL. Rules of PRof'L CONDuCT r. 3-100(b) (2004); D.C. Rules of PRof'L Conduct r. 1.6(c)(d)(e) (2010); Del. Rules OF PROF'L CONDUCT r. 1.6(b) (2010); Fla. Rules OF Prof'L CONDUCT r. 4-1.6(b), (c) (2015); KAN. Rules OF PROF'L CONDUCT r. 1.6(b) (2014); ME. RULES OF PRof'L Conduct r. 1.6(b) (2014); MinN. Rules of PROF'L CONDUCT r. 1.6(b) (2015); Miss. Rules OF Prof'l Conduct r. 1.6(b) (2016); Mo. Rules of Prof'L Conduct r. 1.6(b) (2007); MonT. Rules of PROF'L CONDUCT r. $1.6(\mathrm{~b})$ (2004); N.Y. Rules OF PROF'L CONDUCT r. 1.6 (b) (2014); N.C. RULES OF PROF'L CONDUCT r. 1.6(b) (2014); OHIO RULES OF PROF'L CONDUCT r. 1.6(b) (2016); PA. RULES OF PROF'L CONDUCT r. 1.6(c) (2013); S.D. RULES OF PROF'L CONDUCT r. 1.6(b) (2004); TENN. RULES OF Prof'l Conduct r. 1.6(b) (2015); TeX. Rules of Prof'L CoNduct r. 1.05(c (1995)); and VA. Rules OF PROF'L CONDUCT r. 1.6(b)(c) (2016). 


\begin{tabular}{|c|c|c|c|}
\hline & & $\begin{array}{l}\text { when lawyer's } \\
\text { services are being } \\
\text { used to commit } \\
\text { the fraud) }\end{array}$ & $\begin{array}{l}\text { when lawyer's } \\
\text { services are being } \\
\text { used to commit the } \\
\text { crime) }\end{array}$ \\
\hline Florida & Yes & $\begin{array}{lr}\text { No } & \text { (doesn't } \\
\text { mention } & \text { fraud } \\
\text { explicitly, } & \text { but } \\
\text { does say } & \text { "to } \\
\text { prevent } & \text { client } \\
\text { from committing a } \\
\text { crime") }\end{array}$ & $\begin{array}{l}\text { Yes (lawyer must } \\
\text { reveal to prevent a } \\
\text { general "crime" or } \\
\text { death or substantial } \\
\text { bodily harm) }\end{array}$ \\
\hline Kansas & Yes & $\begin{array}{lr}\text { No } & \text { (doesn't } \\
\text { mention fraud } \\
\text { explicitly, but } \\
\text { does say } \quad \text { "to } \\
\text { prevent client } \\
\text { from committing a } \\
\text { crime") }\end{array}$ & $\begin{array}{l}\text { Yes (generally to } \\
\text { prevent a "crime") }\end{array}$ \\
\hline Maine & $\begin{array}{lr}\text { No } & \text { (lawyer } \\
\text { can reveal if } \\
\text { ME. Rule of } \\
\text { Prof'1 } & \text { Conduct } \\
1.6 \quad \text { would } \\
\text { allow) }\end{array}$ & $\begin{array}{l}\text { Yes (but only } \\
\text { when lawyer's } \\
\text { services are being } \\
\text { used to commit } \\
\text { the fraud) }\end{array}$ & $\begin{array}{l}\text { Yes (but only } \\
\text { when lawyer's } \\
\text { services are being } \\
\text { used to commit the } \\
\text { crime) }\end{array}$ \\
\hline Minnesota & $\begin{array}{lr}\text { No } & \text { (lawyer } \\
\text { can reveal if } \\
\text { Minn. Rule of } \\
\text { Prof'1 } & \text { Conduct } \\
1.6 \quad \text { would } \\
\text { allow) }\end{array}$ & $\begin{array}{l}\text { Yes (but only } \\
\text { when lawyer's } \\
\text { services are being } \\
\text { used to commit } \\
\text { the fraud) }\end{array}$ & $\begin{array}{l}\text { Yes (generally to } \\
\text { prevent a "crime") }\end{array}$ \\
\hline Mississippi & Yes & Yes & Yes \\
\hline Missouri & Yes & No & $\begin{array}{l}\text { No (only to } \\
\text { prevent death or } \\
\text { substantial bodily } \\
\text { harm) }\end{array}$ \\
\hline Montana & Yes & No & (only \\
\hline
\end{tabular}




\begin{tabular}{|c|c|c|c|}
\hline & & & $\begin{array}{l}\text { prevent reasonably } \\
\text { certain death or } \\
\text { substantial bodily } \\
\text { harm) }\end{array}$ \\
\hline New York & \begin{tabular}{lr} 
No & \multicolumn{2}{r}{ (lawyer } \\
can reveal if \\
N.Y. Rule of \\
Prof'l Conduct \\
$1.6 \quad$ would \\
allow)
\end{tabular} & $\begin{array}{l}\text { No (except to } \\
\text { withdraw a written } \\
\text { or oral opinion or } \\
\text { representation that } \\
\text { is being used to } \\
\text { further a fraud or } \\
\text { crime) }\end{array}$ & $\begin{array}{l}\text { Yes (generally to } \\
\text { prevent a "crime") }\end{array}$ \\
\hline $\begin{array}{l}\text { North } \\
\text { Carolina }\end{array}$ & $\begin{array}{l}\text { No (lawyer } \\
\text { can reveal if } \\
\text { N.C. Rule of } \\
\text { Prof'l Conduct } \\
1.6 \quad \text { would } \\
\text { allow) }\end{array}$ & $\begin{array}{l}\text { Yes (but only to } \\
\text { prevent, mitigate, } \\
\text { or rectify the } \\
\text { consequences of } \\
\text { client's fraud for } \\
\text { which the } \\
\text { lawyer's services } \\
\text { were used) }\end{array}$ & $\begin{array}{l}\text { Yes (generally to } \\
\text { prevent a "crime") }\end{array}$ \\
\hline Ohio & $\begin{array}{l}\text { No (lawyer } \\
\text { can reveal if } \\
\text { Ohio Rule of } \\
\text { Prof'l } \\
\text { Conduct. } 1.6 \\
\text { would allow) }\end{array}$ & No & $\begin{array}{l}\text { Yes (generally to } \\
\text { prevent a "crime") }\end{array}$ \\
\hline Pennsylvania & Yes & $\begin{array}{l}\text { Yes (but only to } \\
\text { prevent, mitigate, } \\
\text { or rectify the } \\
\text { consequences of } \\
\text { client's fraud for } \\
\text { which the } \\
\text { lawyer's services } \\
\text { were used) }\end{array}$ & Yes \\
\hline $\begin{array}{l}\text { South } \\
\text { Dakota }\end{array}$ & Yes & No & $\begin{array}{l}\text { No (only to } \\
\text { prevent imminent } \\
\text { death or substantial } \\
\text { bodily harm) }\end{array}$ \\
\hline
\end{tabular}




\begin{tabular}{|c|c|c|c|}
\hline Tennessee & $\begin{array}{l}\text { No (lawyer } \\
\text { can reveal if } \\
\text { Tenn. Rule of } \\
\text { Prof'l Conduct } \\
1.6 \quad \text { would } \\
\text { allow) }\end{array}$ & $\begin{array}{l}\text { Yes (but only } \\
\text { when lawyer's } \\
\text { services are being } \\
\text { used to commit } \\
\text { the fraud) }\end{array}$ & Yes \\
\hline Texas & $\begin{array}{l}\text { No (lawyer } \\
\text { can reveal if } \\
\text { Tex. Rule of } \\
\text { Prof'l Conduct } \\
1.05 \text { would } \\
\text { allow) }\end{array}$ & Yes & $\begin{array}{l}\text { Yes (generally to } \\
\text { prevent a "criminal } \\
\text { act") }\end{array}$ \\
\hline Virginia & Yes & $\begin{array}{l}\text { No (but only after } \\
\text { client has } \\
\text { perpetrated a fraud } \\
\text { related to the } \\
\text { subject matter of } \\
\text { the representation) }\end{array}$ & $\begin{array}{l}\text { Yes (lawyer must } \\
\text { reveal to prevent a } \\
\text { general "crime") }\end{array}$ \\
\hline $\begin{array}{l}\text { Washington, } \\
\text { D.C. }\end{array}$ & $\begin{array}{l}\text { No (lawyer } \\
\text { can reveal if } \\
\text { D.C. Rule of } \\
\text { Prof'l Conduct } \\
1.6 \quad \text { would } \\
\text { allow) }\end{array}$ & $\begin{array}{l}\text { Yes (but only } \\
\text { when lawyer's } \\
\text { services are being } \\
\text { used to commit } \\
\text { the fraud) }\end{array}$ & $\begin{array}{l}\text { Yes (but only } \\
\text { when lawyer's } \\
\text { services are being } \\
\text { used to commit the } \\
\text { crime) }\end{array}$ \\
\hline
\end{tabular}

This chart demonstrates the lack of consistency among the Non-Adopting States with respect to when external permissive disclosures are permitted. The lack of conformity between the permissive disclosures of the Part 205 Rules/Model Rule 1.13 and the policies of the Non-Adopting States presents an unwieldy paradigm for attorneys who appear and practice before the SEC. In addition, this inconsistency poses to lawyers-who are subject to the Part 205 Rules but also admitted in a Non-Adopting State-the difficulty of establishing whether they are eligible for whistleblower retaliation protections under DoddFrank if the Fifth Circuit's view prevails and they have made only an internal report. 
The information in the chart above reveals that, in a majority of the NonAdopting States, an attorney who has exhausted internal reporting options under Rule 1.13 would have to rely on a separate rule to find a way to report the information externally. In at least five states, it would never be possible for attorneys, whether under Rule 1.13 or Rule 1.6 , to ethically report to the SEC violations likely to result in substantial financial injury, as these states allow disclosures only to prevent imminent death or substantial bodily harmconcerns that are usually not relevant to a corporate entity. ${ }^{162}$ Another common qualifier in nearly half of the states in Table 1 is that the lawyer's services must be used to further the crime or fraud before the lawyer can reveal information to prevent such crime or fraud. ${ }^{163}$ These types of disclosures are more restrictive than the Part 205 Rules and Model Rule 1.13, which allow an attorney to reveal information whether or not his/her services are being used to perpetrate the crime or the fraud. ${ }^{164}$ Such disclosures would allow an in-house attorney who discovers that an organization or its constituents are engaging in fraudulent or criminal activity to take action, such as self-reporting to the SEC, to remediate the misconduct and mitigate harm to the organization regardless of whether or not he/she is involved in the crime.

Another problematic result stemming from the inconsistency among state rules is the lack of a uniform civil fraud exception to the duty of confidentiality. In several of the states in Table 1, attorneys are barred from making disclosures to prevent civil frauds likely to result in substantial financial injury-activity that is clearly protected under the Part 205 Rules and fits comfortably within Model Rule 1.13. ${ }^{165}$ To illustrate the point, a lawyer admitted in New York is permitted under Rule 1.6 to reveal confidential information to the extent he/she reasonably believes necessary (i) to prevent death or bodily harm; (ii) to

162. See supra note 161 for Rule 1.6 or the equivalent thereof in these states. Thus, attomeys admitted in Alabama, California, Missouri, Montana, and South Dakota who appear and practice before the SEC would never be able to ethically rely on the Part 205 Rules's permissive disclosures.

163. Such is the case in Delaware, Maine, Minnesota, Mississippi, North Carolina, Pennsylvania, Tennessee, and Washington, D.C., as it pertains to a permissive crime or fraud disclosure, respectively. Each of these states, excluding Minnesota, also allows a lawyer to so disclose if necessary, not just to "prevent" substantial financial injury, but also to "mitigate" or "rectify" it when the client uses the lawyer's services in furtherance of the wrongdoing. See supra note 161 for Rule 1.6 or the equivalent thereof in these states. In Minnesota, South Dakota, and Texas, this type of disclosure is limited to disclosures that "rectify" the consequences of a client's criminal or fraudulent conduct in furtherance of which the lawyer's services are being used, and, in Ohio, it is only available to "mitigate" such consequences. See id.

164. 17 C.F.R. $\$ 205.3(d)(2)(i)$, (ii) (2010). Prong (iii) of 17 C.F.R. $\$ 205.3(d)(2)$ contains a qualifier requiring that the attorney's services be used prior to disclosure but only as the attorney reasonably believes necessary to rectify the consequences of a material violation resulting in substantial financial injury to the issuer or investors.

165. See $i d$. $\S 205.3(\mathrm{~d})(2)(\mathrm{i})$. Such is the case in Alabama, California, Florida, Kansas, Missouri, Montana, New York, Ohio, South Dakota, and Virginia. See supra note 161 for Rule 1.6 or the equivalent thereof in these states. 
prevent the client's commission of a crime; (iii) to withdraw an opinion or representation previously given by the lawyer based on materially inaccurate information or that is being used to further a crime or fraud; (iv) to secure legal advice about compliance with ethical rules; (v) to defend the lawyer against an accusation of wrongful conduct or to establish or collect a fee; or (vi) when permitted or required under the rules of professional conduct or to comply with another law or court order. ${ }^{166}$ If an attorney admitted in New York has reported up the ladder only to be faced with an unresponsive board or one insistent on carrying out the civil violation, it would be very difficult for that attorney to argue that he/she could then externally report this information. ${ }^{167}$ Under New York's Rule 1.6, one might normally expect the second exception listed above to apply: "to prevent the client's commission of a crime." However, it would not apply to prevent the client from committing a civil fraud, even though this could be just as damaging as a criminal act to the organization. ${ }^{168}$ In addition, absolutely none of the Non-Adopting States-and no other state for that matter-permits a lawyer to disclose client information in order to prevent the client from committing a "material violation" of a civil statute that would constitute non-fraudulent conduct likely to cause substantial financial injury, despite the inclusion of this type of reporting in the Part 205 Rules. ${ }^{169}$

Given the risk that attorneys following the Part 205 Rules might violate conflicting state law, ${ }^{170}$ the question of preemption naturally arises: Do the Part 205 Rules trump conflicting state ethical rules for attorneys who practice before the SEC? This is a question that no court has yet determined. ${ }^{171}$

166. N.Y. RULES OF PROF'L CONDUCT R. 1.6(b) (2014).

167. See, e.g., Temkin \& Moskovits, supra note 19, at 19-21 (analyzing the discrepancies among the Model Rules, state ethics rules, and the Part 205 Rules).

168. See N.Y. RULES OF PROF'L CONDUCT R. 1.6(b) (2014) (emphasis added); see also Temkin \& Moskovits, supra note 19, at 19-21 (discussing potential for conflicts with state ethical rules); McLucas et al., supra note 18 (discussing lack of uniformity in this reporting context).

169. McLucas et al., supra note 18, at 5; see also 17 C.F.R. $\$ 205.3$ (d)(i) (2010) (this subsection allows an attorney to reveal confidential information to the extent reasonably believed necessary to "prevent the issuer from committing a material violation that is likely to cause substantial injury to the financial interest or property of the issuer or investors").

170. See Faqihi, supra note 18, at 3381-90 (discussing the intersection of the various federal and state laws imposed on attorney-whistleblowers and their potential for conflict).

171. Temkin \& Moskovits, supra note 19, at 19; see also Clark \& Moore, supra note 19, at 1747 (noting that the question of whether the attorney reporting rules under SOX preempt conflicting state law has never been resolved). Clark and Moore also note that this question may be unanswered perhaps because no lawyers have decided to make a permissive disclosure that was prohibited under the applicable state ethical rule. See Roger C. Cramton et al., Legal and Ethical Duties of Lawyers after Sarbanes-Oxley, 49 VILL. L. REV. 725, 808 (2004). Clark and Moore note that lawyers may now start to make such disclosures given the possibility that they may receive a bounty for doing so under Dodd-Frank. See id.; see also Bruce Green \& Jordan Thomas, Approaching Attorney Whistleblowing Post Dodd-Frank, LAw360 (Apr. $11, \quad$ 2012), http://www.law360.com/articles/325874/approaching-attorney-whistleblowing-post-dodd-frank (discussing that the possibility of financial rewards under Dodd-Frank could prompt attorneys to become whistleblowers). 


\section{A. Preemption of Part 205 Rules over Inconsistent State Ethical Rules}

\section{Opposition to Preemption}

The author finds no conflict between the mandatory up-the-ladder disclosure requirements of the Part 205 Rules and state ethical rules, because all of the reports would remain within the confines of the client organization itself. Therefore, this Section will only address the more controversial of the two types of attorney-whistleblowing, permissive disclosure, and assess only whether the permissive disclosure rules preempt conflicting state law. ${ }^{172}$

The permissive disclosure rules emphasize that attorneys may use their discretion to reveal confidential information to the $\mathrm{SEC}$ if they reasonably believe it necessary to prevent or mitigate substantial financial harm to the organization. In the absence of preemption, opting to make such a disclosure would subject an attorney admitted in a Non-Adopting State to disciplinary proceedings for breaching the duty of confidentiality. As an alternative to reporting, an attorney facing this predicament may opt to remain silent, thereby allowing the organization's misconduct to endure and possibly advance to more egregious levels. Both of these options are unsettling.

A court that examines the issue of preemption in this context should find that the state rules conflicting with the Part 205 Rules pose an obstacle to achieving the full objectives of SOX's Section 307 and are thus subject to statutory preemption. ${ }^{173}$ In the alternative, an argument for administrative preemption through the SEC's duly authorized Part 205 Rules is strongly supported. Some scholars and commentators who have examined this issue are of the view that the SEC had full authority to promulgate the Part 205 Rules as written. $^{174}$

Legal scholars have debated whether the Part 205 Rules preempt conflicting state law, and certain states have fiercely opposed the idea. ${ }^{175}$ The

172. Cramton et al., supra note 171 , at 788 (noting that the first public challenges to the SEC Part 205 Rules addressed the "validity and preemptive effect" of the permissive disclosure rules).

173. See infra Part IV.A.2.

174. See, e.g., Cramton et al., supra note 171, at 788-90 (discussing the arguments in favor of preemption); Bruce Green \& Jordan Thomas, Balancing Conscience and Confidentiality for Attorney Whistleblowers, CorP. COuNs. (June 6, 2012), http://knowledgenetwork.labaton.com/Balancing-Conscience-and-Confidentiality.cfm ("There is little doubt that Rule 205.3 was validly enacted by the SEC because Congress required the agency to set minimum attorney-conduct rules in Section 307 of the Sarbanes-Oxley Act."); Sara Levy, The SEC, The States and Attorney Conduct Rules: An Analysis of Preemption Issues, 32 HoFSTRA L. REV. 1681, 1720 (2004) (taking the position that the Part 205 Rules would likely preempt conflicting state ethics rules).

175. Panel 2: The Evolution of Corporate Governance, The Evolving Legal and Ethical Role of the Corporate Attomey After the Sarbanes-Oxley Act of 2002, 52 AM. U. L. REV. 613, 614-27 (2002) [hereinafter Panel] (noting that "there has been no shortage of controversy" regarding the 
arguments against preemption largely center on the concern that the SEC has exceeded its authority by seeking to regulate attorney-client communications, an area that is traditionally the domain of the states, ${ }^{176}$ and promulgating rules that extend beyond the explicit congressional mandate in SOX's Section $307 .{ }^{177}$ For instance, the California State Bar has noted that the preemption claim "has not been tested in court" and questioned whether Congress intended the SEC to have the authority to preempt state ethical rules governing attorney behavior. ${ }^{178}$ Similarly, the Washington State Bar adopted a proposed interim formal ethics opinion challenging the premise that the Part 205 Rules preempt conflicting state law due to the lack of case law on the matter and ultimately took the view that the Part 205 Rules' permissive disclosures must yield to state law that prohibits such disclosures. ${ }^{179}$ As such, the opinion advised Washington attorneys that they could be in compliance with the state's ethical rules by simply opting not to utilize the permissive disclosure available under the Part 205 Rules. ${ }^{180}$ At least one commentator has expressed that such a reading "render[s] [the Part 205 Rules] impotent" by barring the possibility that those permissive disclosures are ever available to Washington attorneys. ${ }^{181}$ These concerns, and others, in opposition to preemption will be addressed below.

Part 205 Rules and discussing news media reporting that "attorneys from coast to coast criticize the SEC's proposals"); see Keith Paul Bishop et al., Conflicting Currents: The Obligation to Maintain Inviolate Client Confidences and the New SEC Attorney Conduct Rules, 32 PEPP. L. REV. 89, 129-30 (2004) (noting that "[s]everal bar associations questioned the SEC's authority to preempt state laws or rules governing attorney-client confidentiality"); John C. Coffee, Jr., The Attorney as Gatekeeper: An Agenda for the SEC, 103 CoLUM. L. REV. 1293, 1294 (2003) (describing bar associations in their reactions to the Part 205 Rules as "locked in denial" and having "the same shocked alacrity of a patient in the dental chair when the drill hits an exposed nerve, they have answered: 'You don't understand; lawyers can't undertake the obligations that you are proposing because they conflict with our duties to our clients"').

176. Temkin \& Moskovits, supra note 19, at 19-21 (arguing that it is violative of the Constitution for the "federal government [to have] the right to license or regulate the practice of law").

177. See, e.g., Matthew Eslick, Tension Among Section 307 of the Sarbanes-Oxley Act of 2002, 17 C.F.R. $\S 205.3(d)(2)$, and State Rules Governing Disclosure of Confidential Client Information, 53 DRAKE L. REV. 133, 157-59 (2004) (noting that the SEC regulations go beyond the "exact wording of Section 307" (citing Letter from Frederick D. Lipman, Blank Rome Comisky \& McCaulley, LLP, to Jonathan G. Katz, Sec'y, Sec. \& Exch. Comm'n (Nov. 27, 2002))); Panel, supra note 175, at 619,621 (statements of Prof. Painter and Prof. Karmel).

178. State B. of Cal. Ethics, The New SEC Attorney Conduct Rules v. California's Duty of Confidentiality, ETHICS HotLINER, Spring 2004; see also Bishop et al., supra note 175, at 129 (expressing the legal conflicts between the California Bar's statutory mandates to maintain client confidences and the SEC's Part 205 Rules and advising lawyers admitted in California that "prudence dictates" that they follow the California's prohibition on reporting externally "unless and until the validity of the SEC's permissive disclosure rule is resolved by an appellate court in the SEC's favor").

179. See Roy Simon, Washington State Bar Takes on the SEC, N.Y. PROF'L RESP. REP. (Oct. 2003) (discussing the "cryptic conclusion" reached by the Washington Bar); Ethics 2003 Comm. of Wash. State B. Ass'n., Internal Formal Ethics Opinion 2003, WASH. ST. B. Ass'N, http://www.wsba.org/lawyers/groups/ethics2003/formalopinion.doc.

180. Ethics 2003 Comm. of Wash. State B. Ass'n, supra note 179.

181. Eslick, supra note 177 , at 153. 


\section{Statutory Preemption}

Courts consider questions of statutory preemption as either express (set forth in the language of the statute) or implied (contained within the statute's "structure and purpose"). ${ }^{182}$ On the face of Section 307 of SOX, which ordered the SEC to promulgate the Part 205 Rules, Congress included no language evidencing an express intent to preempt conflicting state law. ${ }^{183}$ Given the lack of explicit language in the statute itself to support express preemption, the inquiry turns on whether there is implied preemption.

The "frustration of federal purpose" doctrine, also known as "obstacle preemption," is applied in cases of implied preemption; it holds that a state law is preempted when it "stands as an obstacle to the accomplishment and execution of the full purposes and objectives of Congress."184 Obstacle preemption occurs when a state law "interferes with the methods by which a federal statute was intended to reach [its] goal." ${ }^{185}$ The goal of Section 307, as evidenced by its legislative history, was to impose some level of accountability on attorneys representing corporate entities that engaged in fraudulent misconduct leading to scandals like Enron and WorldCom. ${ }^{186}$ Executives and accountants who played a key role in such scandals "[did] not work alone...

182. Morales v. Trans World Airlines, Inc., 504 U.S. 374, 383 (1992). The premise that federal law trumps state law is embodied in the Supremacy Clause of the U.S. Constitution, which declares that the Constitution, treaties, and valid federal statutes are the "supreme Law of the Land." See U.S. Const. art. VI, cl. 2; Caleb Nelson, Preemption, 86 VA. L. REV. 225, 245 (2000).

183. 15 U.S.C. $\S 7245$ (2012). The language of the statute calls upon the SEC to "issue rules, in the public interest and for the protection of investors, setting forth minimum standards of professional conduct for attorneys appearing and practicing before the Commission." No reference to preemption is made.

184. Arizona v. United States, 132 S. Ct. 2492, 2495 (2012) ("[S]tate laws are preempted when they conflict with federal law, including when they stand 'as an obstacle to the accomplishment and execution of the full purposes and objectives of Congress." (citing Hines v. Davidowitz, 312 U.S. 52, 67 (1941))); see also Donald Rothschild, A Proposed "Tonic" with Florida Lime to Celebrate Our New Federalism: How to Deal with the "Headache" of Preemption, 38 U. MIAMI L. REV. 829, 852-53 (1983) (noting that this doctrine originated in 1912 in the decision of Savage v. Jones, 225 U.S. 501 (1912)). Implied preemption occurs when a federal law and a state law conflict, through obstacle preemption, discussed herein, or "impossibility preemption," when it would be impossible for a party to comply with both federal and state law. See Florida Lime \& Avocado Growers, Inc. v. Paul, 373 U.S. 132, 142-43 (1963). Given that an attorney could always make the choice not to disclose under the permissive reporting rules if admitted in a jurisdiction not allowing such disclosures, it is not "impossible" for the attorney to comply with both federal and state law. Cramton et al., supra note 171 , at $788-89$ (noting that the SEC rules do not require lawyers to report anything that a state ethical rule would prohibit, but "do two other things: require something (i.e., reporting up) that some state rules may merely permit; and permit something (i.e. reporting out) that some state rules prohibit or restrict").

185. Gade v. Nat'l Solid Wastes Mgmt. Ass'n, 505 U.S. 88, 90 (1992); see also Columbia Venture, LLC v. Dewberry \& Davis, LLC, 604 F.3d 824, 829-30 (4th Cir. 2010) (noting that courts, in considering obstacle preemption, must consider the national interests at stake and their "putative conflict with state interests").

186. 148 CONG. REC. S6524-02, S6552 (daily ed. July 10, 2002); see also Fanto, supra note 5 , at 477,491 (discussing the role of corporate advisors like bankers, lawyers, and accountants in notable financial scandals). 
[as] lawyers are virtually always there looking over their shoulder." ${ }^{187}$ SOX's legislative history notes that lawyers had "forg[otten] who their client [wa]s" and that their fiduciary duties are owed to the organization itself, rather than to individual constituents with whom attorneys may have the most daily contact. ${ }^{188}$ The goal of Section 307 was to prompt lawyers to take action to thwart unlawful behavior when a violation of the law is imminent or has occurred. ${ }^{189}$ As such, Congress granted broad authority to the SEC to:

\begin{abstract}
[I] ssue rules, in the public interest and for the protection of investors, setting forth minimum standards of professional conduct for attorneys appearing and practicing before the [SEC] ... "including a rule" (1) requiring an attorney to report evidence of a material violation of securities law or breach of fiduciary duty or similar violation by the company or any agent thereof, to the chief legal counsel or the chief executive officer of the company (or the equivalent thereof); and (2) if the counsel or officer does not appropriately respond to the evidence (adopting, as necessary, appropriate remedial measures or sanctions with respect to the violation), requiring the attorney to report the evidence to the audit committee of the board of directors of the issuer or to another committee of the board of directors comprised solely of directors not employed directly or indirectly by the issuer, or to the board of directors. ${ }^{190}$
\end{abstract}

Given this language, the SEC had broad authority to promulgate ethical rules for the attorneys practicing before it that, at a minimum, had to include the two prongs noted above. A comprehensive analysis of the duties of lawyers post-SOX by Roger Cramton, George Cohen, and Susan Koniak concludes that the permissive disclosure rules "fit comfortably" within this broad mandate of Congress. They argue that this is due, in part, to Congress's use of the word "including," which, in the absence of any limiting language, strengthens the notion that Congress granted the SEC wide discretion to implement a general set of rules. ${ }^{191}$ Further, Section 307 had the goal of replacing the former Model Rule $1.13(\mathrm{~b})$, which required a lawyer who knew of a violation likely to result in substantial injury to the organization to "proceed as is reasonably necessary in the best interest of the organization, which may include 'reporting up the board." "192 In this way, preemptive intent is further evident: Congress enacted a statute requiring the SEC to adopt ethical rules different from state ethical rules

Edwards).

187. 148 CONG. REC. S6524-02, S6552 (daily ed. July 10, 2002) (statement of Sen.

188. Id. ("When they go to lunch with their client, the corporation, they are usually going to lunch with the $\mathrm{CEO}$ or the chief financial officer. When they get phone calls, they are usually returning calls to the $\mathrm{CEO}$ or the chief financial officer. The problem is that the CEO and the chief financial officer are not the client.")

189. Id.

190. Rules of Prof'l Responsibility for Attorneys, 15 U.S.C. $\$ 7245$ (2012) (emphasis

added).

191. Cramton et al., supra note 171, at 789-91; see also Clark \& Moore, supra note 19 , at 1761 (finding the SEC's arguments that it was granted authority by Congress to carry out SOX's purpose persuasive but finding the preemptive status of the Part 205 Rules "at least questionable" given that SOX focused on up-the-ladder reporting).

192. Cramton et al., supra note 171, at 792 (citing former MODEL RULES OF PROF'L CONDUCT r. 1.13 (b) (2002)). 
then in place "because the state standards were not sufficiently encouraging of reporting up." 193

It can, therefore, be said that the Part 205 Rules were promulgated to carry out Congress's objective in SOX to "reconsider the [then-prevalent] incentive system ... [, which] encourag[ed] accountants and lawyers who come across fraud in their work to remain silent," 194 by allowing attorneys a mechanism to self-report evidence of misconduct to the governing agency. State law that penalizes lawyers for making such reports in this fairly limited context arguably thwarts the full purposes of SOX to "prevent and punish corporate fraud, protect the victims of such fraud, preserve evidence of such fraud and crime, and hold wrongdoers accountable for their actions" by imposing affirmative duties on lawyers to prevent Enron-like fraud. ${ }^{195}$ For these reasons, such state laws should be preempted by SOX.

\section{Administrative Preemption}

Even if a court were not to find preemption based on the statutory language of Section 307, it should find that preemption is supported by the Part 205 Rules themselves as a valid exercise of the SEC's authority to promulgate these regulations. The Supreme Court has emphasized the "well-entrenched doctrine" 196 that administrative agencies, through duly authorized regulations, have just as much power as Congress does through legislation to preempt conflicting state law, as such regulations have preemptive power over state law that frustrates the purpose or poses an obstacle to the regulations' goals. ${ }^{197}$ As such, the agency's power to preempt is "impliedly transmitted alongside" its general rule-making authority. ${ }^{198}$ To preempt state law, the agency regulation need not rely upon an express authorization by Congress. Instead, the inquiry turns on (i) whether the agency intends to preempt state law and (ii) whether such action is within the scope of the agency's delegated authority. ${ }^{199}$

The first prong is easily supported. The Part 205 Rules include express preemption language, stating "[w]here the standards of a state or other United States jurisdiction where an attorney is admitted or practices conflict with [the Part 205 Rules], [such rules] shall govern."200 Thus, the SEC has clearly

\footnotetext{
193. Id.

194. S. REP. No. 107-146, at 21 (2002).

195. Id. at 2.

(2012).

196. David S. Rubenstein, Delegating Supremacy?, 65 VAND. L. REV. 1125, 1149

197. City of New York v. F.C.C., 486 U.S. 57, 63-64 (1988).

198. Rubenstein, supra note 196, at 1150 (emphasis omitted).

199. Fidelity Fed. Sav. \& Loan Ass'n v. de la Cuesta, 458 U.S. 141, 154 (1982).

20017 C.F.R. $\$ 205.1$ (2016). The Part 205 Rules state that they "supplement" the applicable standards in any jurisdiction in which an attorney is admitted to practice and do not "limit the ability of any jurisdiction to impose additional obligations on an attorney not inconsistent with the application of [these rules]." Id.
} 
demonstrated its intent to preempt conflicting state law on the face of the regulations. Further, shortly after the Part 205 Rules became final and in response to the Washington State Bar's concerns, the SEC, through its thengeneral counsel, Giovanni P. Prezioso, expressed the intent of the rules to preempt conflicting state law, citing relevant Supreme Court authority to do so, and noted that the purpose of the SEC's rules would be "thwart[ed]" if any state were to institute disciplinary proceedings against a lawyer who complied, in good faith, with the rules. ${ }^{201}$

As discussed in the preceding section, the Part 205 Rules, as enacted, are within the scope of the agency's delegated authority. The congressional mandate granted the SEC considerable discretion in promulgating rules governing the conduct of lawyers who appear or practice before it while representing issuers. ${ }^{202}$ In the case of the SEC, the Securities Exchange Act of 1934 grants the SEC broad rulemaking authority to implement the federal securities laws, ${ }^{203}$ including authority to establish its own rules governing the conduct of the professionals who practice before the agency. ${ }^{204}$ The ability of federal agencies to implement rules of conduct governing professionals that may be divergent from or supersede state law also has been authorized through Supreme Court precedent. ${ }^{205}$ The authority on this point is Sperry v. State of Florida, a case in which the Florida Bar sought to enjoin a professional registered to practice before the U.S. Patent Office from performing such work as preparing and prosecuting patent applications, alleging that this constituted the unauthorized practice of law. ${ }^{206}$ Given the existence of a federal statute expressly permitting the Commissioner of Patents to regulate the practice of individuals before the U.S. Patent Office, including non-lawyers, the Supreme Court held that the Florida Bar may not contest such an action on the basis that the federal regulation preempts state law that would hinder or obstruct duly authorized actions of federal agencies to implement rules of professional conduct for those who practice before them. ${ }^{207}$

These principles are equally applicable to the SEC's rulemaking authority under SOX to promulgate standards of professional conduct for attorneys who appear and practice before the agency. As in Sperry, SOX's statutory language expressly permits the SEC to authorize the practice of those professionals who appear before it, thus evidencing a clear congressional intent for federal

201. Letter from Giovanni P. Prezioso, Gen. Counsel, Sec. \& Exch. Comm'n, to J. Richard Manning, President, Wash. State B. Ass'n (July 23, 2003), http://www.sec.gov/news/speech/spch072303gpp.htm.

202. See supra Part IV.A.1.

203. 15 U.S.C. $\$ 78 \mathrm{w}(\mathrm{a})(1)(2012)$.

204. Id. $\$ 78 \mathrm{~d}-3$; 17 C.F.R. $\$ 201.102(\mathrm{e})(1)(2010)$; see also Levy, supra note 174 , at 1688-89 (citing Touche Ross \& Co. v. SEC, 609 F.2d 570 (2d Cir. 1979)); Davy v. SEC, 792 F.2d 1418 (9th Cir. 1986)).

205. Sperry v. Florida ex rel. Fla. Bar, 373 U.S. 379, 384-86 (1963).

206. Id. at $381-82$.

207. Id. at 385 . 
regulation in this specific arena. As Sperry holds, when there has been authorized federal regulation of this kind, states may not exercise a "virtual power of review" over the federal agency's utilization of that power-a right that may otherwise be available in the absence of duly authorized federal regulation. $^{208}$ The congressional language at play here is also broad, capturing lawyers who "in any way" represent issuers. ${ }^{209}$ The congressional mandate to the SEC to establish "minimum standards of professional conduct for attorneys appearing and practicing before the [SEC] in any way in the representation of issuers" ${ }^{210}$ contains no limits to regulate attorneys in this manner. ${ }^{211}$ The SEC mitigated concerns during the rulemaking process that the rules may cast too wide of a net over lawyers who may only tangentially be involved in SEC filing work by limiting the definition of "appearing and practicing." 212 The SEC's clarifications of this definition constitute efforts by the agency to remain well within the scope of its delegated authority while still achieving, to the best of its ability, Section 307's objectives. ${ }^{213}$ "Appearing and practicing" is defined in the final rules as transacting any business with the SEC; representing an issuer in an SEC proceeding or investigation; providing advice with respect to federal securities laws or SEC rules or regulations; or advising issuers as to required SEC disclosures or filings. ${ }^{214}$ In an effort to limit the scope of the targeted audience of the Part 205 Rules, the SEC clarified that attorneys are deemed to "appear and practice" before the SEC only if they have notice that the document that they are preparing or assisting to prepare will be filed with the SEC. ${ }^{215}$ For example, if an attorney prepares a document that he/she never intended to file or had notice would be filed with the SEC or incorporated into an SEC filing, such lawyer is not deemed to have "appeared or practiced" before the SEC even if that document is ultimately filed with the SEC or made part of a filing as an exhibit. ${ }^{216}$ Other limitations include the exclusion of individuals, who, although licensed to practice law, are not in the legal departments of issuers and are not providing legal services "within the context of an attorney-client relationship;" and the exclusion of "non-appearing foreign attorneys" who are admitted in non-U.S. jurisdictions and only incidentally to,

208. See id. at 385 .

209. See 15 U.S.C. $\$ 7245$ (2012).

210. Id. (emphasis added).

211. See Fidelity Fed. Sav. \& Loan Ass'n v. de la Cuesta, 458 U.S. 141, 161-62 (1982) (upholding the authority of an agency to regulate lending practices of federal savings and loans due to no limits on its authority to do so in the governing statute's language).

212. Final Rules, Implementation of Standards of Professional Conduct for Attorneys, 68 Fed. Reg. 6296, 6297-98 (Feb. 6, 2003) [hereinafter Final SOX Rules].

213. Id at 6303 .

214. 17 C.F.R. $\$ 205.2(a)(2014)$.

215. Final SOX Rules, supra note 212, at 6298.

216. Id. 
or in consultation with, U.S. attorneys, conduct activities that would otherwise qualify as appearing and practicing before the SEC. ${ }^{217}$

As such, it can be reasonably interpreted that the SEC's adoption of permissive disclosure rules is a valid exercise of the agency's authority and that the Part 205 Rules would trump conflicting state law.

\section{B. Clarity to the Attorney-Whistleblowing External Reporting Trigger}

For these reasons, courts should find that the Part 205 Rules preempt conflicting state law, which would require the Non-Adopting States to yield to the standards of professional conduct set forth in the Part 205 Rules. Such a result is likely to prompt resistance not only by the Non-Adopting States but by corporate clients, who could argue that lawyers may prematurely report sensitive information externally without taking all internal efforts to remedy the problem. Concerns to this effect may be mitigated by ensuring with absolute clarity that an attorney's permissive disclosure option in the Part 205 Rules is only available after internal reporting mechanisms have been fully exhausted, thereby allowing a disclosure to the SEC only as a last resort. ${ }^{218}$ As the Part 205 Rules stand, this requirement is not entirely clear.

The triggering mechanism allowing an attorney to reveal confidential information to the SEC to prevent substantial financial injury or other specified unlawful conduct is the "reasonable belief" standard. ${ }^{219}$ The definitions of "reasonably believes" and "reasonable" in the Part 205 Rules and the ABA Model Rules are nearly identical; the former requires an attorney to "believe[] the matter in question and that the circumstances are such that the belief is not unreasonable," and the latter "denotes conduct that would not be unreasonable for a prudent and competent attorney." 220 Despite these similarities, the language of the Part 205 Rules and ABA's Model 1.13 differ in one important respect.

ABA's Model Rule 1.13 makes clear that a permissive disclosure requiring a reasonable belief on the part of the attorney is only available if "the highest authority that can act on behalf of the organization insists upon or fails to address in a timely and appropriate manner an action, or a refusal to act, that is clearly a violation of law."221 Thus, an exhaustion of internal reporting channels is necessary before an attorney may report externally. Although the

217. Id; see also 17 C.F.R. $\$ \S 205.2(\mathrm{a})$, (j) (2014) (setting forth the definitions of "appearing and practicing" before the SEC and "non-appearing foreign attorney.").

218. Naseem Faqihi proposed that in-house attorneys, who may be subject to more than one governing law or ethical rule, should be uniformly subject to a "two-tiered reporting standard," which would require them to report internally first and then externally if the violation has not been resolved, which would allow such attorneys to expose misconduct without the risk of violating conflicting laws. See Faqihi, supra note 18, at 3390-94.

219. 17 C.F.R. $\$ 205.3$ (d) (2014).

220. Id. $\$ 205.2(\mathrm{l}),(\mathrm{m})$; MODEL RULES OF PROF'L CONDUCT r. $1.0(\mathrm{~h})(\mathrm{i})(2003)$.

221. MODEL RULES OF PROF'L CONDUCT r. 1.13 (c) (2003). 
up-the-ladder reporting requirements are mandatory in the Part 205 Rules and may be implied as prerequisites to reporting externally, neither 17 C.F.R. $\S$ 205.3(d), which codifies the permissive disclosure option, nor the final SEC rules implementing these requirements, is so explicit as to mandate this exhaustion of internal reporting before externally disclosing confidential information. $^{222}$ This absence leaves open the possibility that an attorney appearing and practicing before the SEC may opt to report information to the SEC without having first exhausted internal reporting requirements to the specified chief officers or a qualified legal compliance committee and, ultimately, the board. To avoid this possibility, the language in 17 C.F.R. $\$$ 205.3(d) should be amended to include language similar to that found in Model Rule 1.13 clarifying that an external disclosure to the SEC is permitted only if the mandatory up-the-ladder reporting requirements have been exhausted and the board of directors or qualified legal compliance committee "insists upon" or "fails" to adopt an "appropriate response" to the violation.

"Appropriate response" or lack thereof is used elsewhere in the Part 205 Rules as the prompt for which the attorney must report up the ladder to the board and would be fitting for inclusion in the permissive disclosure section as well. "Appropriate response" is defined to include the issuer's efforts to address unlawful conduct such as (i) a finding that no actual material violation has occurred or will occur; (ii) adoption by the issuer of remedial measures, including "appropriate steps or sanctions" to stop ongoing material violations, to prevent those that may yet occur, or to minimize the likelihood of recurrence of those that have occurred; or (iii) the retention of an attorney to review the reported evidence of a material violation, who has reasonably investigated such information and remediated it, or advised that a colorable defense on behalf of the issuer may be asserted by the attorney in any investigation, judicial, or administrative proceeding. ${ }^{223}$

The measures enumerated above, or some variation of them, evidence a good faith effort on the part of the issuer to address the violation that the attorney has reported. While the need for an internal report prior to permissively disclosing may not be ideal or necessary for typical employeewhistleblowers who often face organizational pressures to avoid dissent, ${ }^{224}$ such a requirement is justified for attorney-whistleblowers who are subject to other ethical duties requiring them to act in the best interests of the organization. For example, Model Rule 1.2 bars a lawyer from counseling or assisting a client to engage in conduct that the lawyer knows to be criminal or fraudulent, thereby barring an attorney from sitting idle when he/she becomes

222. See 17 C.F.R. $§ 205.3$ (d) (2015); Final SOX Rules, supra note 212.

223. 17 C.F.R. $\$ 205.2$ (b) (2015).

224. See, e.g., Fanto, supra note 5, at 466-67 (discussing the social psychological theory of groupthink as polarizing whistleblowers who dissent from group consensus); Faqihi, supra note 18, at 3382 (discussing whistleblowing disincentives, including situations where the "organizational culture does not allow dissent"). 
aware of unlawful behavior. ${ }^{225}$ Model Rule 2.1 requires a lawyer acting in an advisory role to "exercise independent professional judgment and render candid advice" that may extend beyond the law to cover moral, economic, social, and political considerations that "may be relevant to the client's situation." ${ }^{226}$ This rule exemplifies a policy of "encouraging clients to do more than simply the minimum that would be necessary to avoid legal liability, but further to do what is right because it is the right thing to do." 227 In such instances, internal whistleblowing, which emphasizes the "primary goals of whistleblowing"- to "expose and curtail wrongdoing" - creates much less harm to the interests of the organization. ${ }^{228}$ Corporations relying on internal whistleblowing by attorneys are able to avoid the excessive or damaging penalties, bad publicity, and losses for shareholders that often result from reporting to the government. $^{229}$

If, however, the attorney's report is ignored and executives or board members have become non-responsive to the concerns facing the organization, an external report to the SEC becomes reasonable to protect the best interests of the organization as a separate legal entity. ${ }^{230}$ Self-reporting to the SEC at this particular juncture is beneficial to the organization in that it serves to mitigate penalties and losses of potentially enormous degrees to the organization as a whole, the entity to which the attorney owes his/her fiduciary duties. Further, executives or board members who are not acting in the best interests of the organization may be compelled to take action or remediate their conduct in light of cooperation opportunities with the SEC to decrease potential sanctions they may personally face.

In the SEC's 2001 "Seaboard Report," the SEC laid out its analytical framework for deciding whether to bring an enforcement action against a corporation that has committed wrongdoing and cooperate with wrongdoers who have voluntarily come forward. ${ }^{231}$ The Seaboard Report highlights the importance of self-policing, self-reporting, and remediation as key factors that the SEC will consider in granting leniency to companies or deciding not to proceed with enforcement actions, as such measures by a company avoid the

225. MODEL Rules of PROF'L CONDUCT r. 1.2(d) (2015).

226. Id. r. 2.1.

227. Long, supra note 53, at 1095.

228 Bishara et al., supra note 36 , at 76.

229. See id.; see also Corporate Law-Securities Regulation-Congress Expands Incentives for Whistleblowers to Report Suspected Violations to the SEC, supra note 36, at 1835-36.

230. See Lobel, supra note 30, at 492 (noting that it "becomes reasonable" for an employee to report externally when attempts to address problems from the inside have been futile).

231 See Report of Investigation Pursuant to Section 21(a) of the Securities Exchange Act of 1934 and Commission Statement on the Relationship of Cooperation to Agency Enforcement Decisions, U.S. SEC. \& EXCH. COMM'N (Oct. 23, 2001) [hereinafter Seaboard Report]; see also Enforcement Cooperation Program, U.S. SEC. \& ExcH. CoMM'N (2015), http://www.sec.gov/spotlight/enfcoopinitiative.shtml [hereinafter Enforcement Cooperation Program]; Robert W. Tarun \& Peter P. Tomczak, A Proposal for a United States Department of Justice Foreign Compt Practices Act Leniency Policy, 47 AM. CRIM. L. REV. 153, 167-70 (2010). 
need for expending large government and shareholder resources. ${ }^{232}$ The SEC makes clear that it values the existence of effective compliance procedures and "appropriate tone at the top" even prior to the discovery of misconduct; the "prompt[], "complete[], and "effective[]" self-reporting of misconduct as soon as it is discovered; remedial efforts such as dismissing or disciplining wrongdoers or improving internal controls; and cooperation with the SEC. ${ }^{233}$

The SEC will also consider the length of the misconduct, including whether "senior personnel ... participat[ed] in, or turn[ed] a blind eye toward" it, the length of time after discovery of the misconduct that the entity took to implement an effective response, and the sufficiency of the documentation provided to the SEC surrounding the misconduct. ${ }^{234}$ If a corporation or complicit corporate players have utilized these measures, they may avoid an enforcement action altogether or benefit from a cooperation agreement with the SEC to receive credit for cooperating in related enforcement actions or investigations, a deferred prosecution agreement, or a non-prosecution agreement. ${ }^{235}$ Given the value to the SEC of prompt and complete reporting, empowering attorney-whistleblowers with an external reporting mechanism allows them to act in the best interests of their client-entities by working proactively with the SEC to mitigate the damage to the company. Thus, in the highly likely event that courts hold that the Part 205 Rules preempt conflicting state law, these amendments would ensure that lawyers are able to balance their various ethical duties while acting in the best interests of their clients.

\section{A Middle Ground: A State-Based Solution to Inconsistent Reporting Requirements}

Although this Article takes the position that the Part 205 Rules should prevail in a preemption analysis, no judicial determination to this effect has yet been made. As discussed, public opposition to the Part 205 Rules has expressed that, in the absence of case law confirming preemption of conflicting state law, attorneys admitted in jurisdictions with differing rules cannot be said to be abiding by those rules in good faith. ${ }^{236}$ This Section will explore an alternative state-based solution aimed at achieving uniformity in the reporting obligations of attorneys.

232. See Seaboard Report, supra note 231; Enforcement Cooperation Program, supra note 231, and Tarun \& Tomczak, supra note 231, at 167-70.

supra note 231

233. See Enforcement Cooperation Program, supra note 231; Seaboard Report,

234. See Seaboard Report, supra note 231.

235. See Enforcement Cooperation Program, supra note 231.

236. At the time that the Part 205 Rules were promulgated, some states publicly reacted with opposition to the preemption of the rules over conflicting state law, advising attorneys admitted in their jurisdictions not to make permissive disclosures. See, e.g., Bishop et al., supra note 175 (discussing opposition by the California Bar); Ethics 2003 Comm. of Wash. State B. Ass'n, supra note 179 . 
As discussed, all of the states have adopted some version of Model Rule 1.13, which imposes responsibilities on lawyers who represent organizations as clients. ${ }^{237}$ As it stands, the permissive disclosure aspect of ABA's Model Rule 1.13 (c) reads as follows:

\begin{abstract}
[I]f (1) despite the lawyer's [up-the-ladder reporting] efforts . . . the highest authority that can act on behalf of the organization insists upon or fails to address in a timely and appropriate manner an action, or a refusal to act, that is clearly a violation of law, and (2) the lawyer reasonably believes that the violation is reasonably certain to result in substantial injury to the organization, then the lawyer may reveal information relating to the representation whether or not Rule 1.6 permits such disclosure, but only if and to the extent the lawyer reasonably believes necessary to prevent substantial injury to the organization.
\end{abstract}

As is evident through this language, the $\mathrm{ABA}$ has taken the position that efforts to thwart wrongdoing through disclosure-when reasonably believed necessary to prevent substantial financial injury-should trump concerns about breaching the duty of confidentiality. ${ }^{239}$ Interestingly, "organization" is not explicitly defined in the Model Rules. Instead, the comments thereto describe "organization" simply as a "legal entity," 240 thereby utilizing the "entity theory" to make clear that the organization itself is the client as opposed to its individual constituents, which may be officers, directors, shareholders, or other stakeholders. ${ }^{241}$ The comments to Model Rule 1.13 also state that these rules "apply equally to unincorporated associations." 242 Thus, the language of Model Rule 1.13 leaves considerable leeway for lawyers to make a permissive disclosure no matter what type of entity they represent, whether large or small, public or private, incorporated or not, and across any industry. Although the ABA was mostly concerned with lawyers representing public companies when it amended the rules in 2003, inclusion of the term "organization" ensured that the ability to permissively disclose would be available to lawyers representing "a wide variety of entities, including non-public companies, labor unions, charities, and other nonprofit organizations, governmental agencies, and unincorporated entities." 243

In addition, Model Rule 1.13 does not make any limitation on the person or entity to whom the lawyer may permissively disclose the information, as the rule includes general language stating that "the lawyer may reveal information relating to the representation ...,"244 This implies that the lawyer using his/her discretion to externally report would be permitted to disclose to any person or entity, whether it is a third party that might suffer financial injury from the

\footnotetext{
237. See Part III.A.

238. MODEL RULES OF PROF'L CONDUCT r. 1.13(c) (2003).

239. See id.

240. MODEL Rules OF PROF'L CONDUCT r. 1.13, cmt. 1 (2003).

241. Id.; Bost, supra note 8, at 359-60.

242. MODEL RULES OF PROF'L CONDUCT r. 1.13 \& cmt. 1 (2003)

243. Bost, supra note 8, at 359-60.

244. MODEL RULES OF PROF'L CONDUCT r. 1.13 (2003).
} 
client's misconduct, a court, an administrative agency, or any other person. In stark contrast, the Part 205 Rules allow a similarly situated attorney to reveal confidential information only to the SEC itself. ${ }^{245}$

Given the breadth of Model Rule 1.13's coverage, it is perhaps understandable that the rule has not been adopted by all fifty states. Each of the Non-Adopting States, however, has included language in their versions of Rule 1.13 instructing lawyers of their options in the event that the highest authority within the organization insists upon or ignores the misconduct after the attorney's internal report to that authority-whether such actions include resignation or reporting if permitted under Rule 1.6. ${ }^{246}$ This language tends to take the following form:

\begin{abstract}
If, despite the lawyer's [up-the-ladder reporting] efforts, the highest authority that can act on behalf of the organization insists upon action, [or fails to address in a timely and appropriate manner an action] or a refusal to act, that is clearly a violation of law and is likely to result in substantial injury to the organization, the lawyer may resign [in accordance with the applicable resignation rule] [and/or] reveal confidential information if permitted by [and only to the extent permitted to do so by] Rule 1.6 [or its equivalent]. ${ }^{247}$
\end{abstract}

As a reasonable middle ground, the following language or some variation thereof could be appended to the end of this clause in the equivalent of Model Rule 1.13 in the Non-Adopting States: "or, if the lawyer is appearing and practicing before the Securities and Exchange Commission in the representation of an issuer (as defined in 17 C.F.R. $\$ 205.2$ ) and is obligated to adhere to the attorney-reporting requirements of 17 C.F.R. $\S 205.3$, the lawyer may reveal confidential information to the Securities and Exchange Commission only as prescribed in such regulations."

State adoption of uniform reporting standards would ensure that attorneys who make external disclosures would not violate their ethical duties in the jurisdiction(s) to which they are admitted. Various scholars have previously

\title{
245. See 17 C.F.R. $\$ 205.3$ (d) (2015).
}

246. See supra Part III.A.

247. See supra notes 155-56 (Rule 1.13 (Organization as Client) or the equivalent thereof in the Non-Adopting States). This is not a direct quote of the applicable rule in any one state but combines the various language of the same rule in each of the Non-Adopting States. Although the equivalents of Rule 1.13 in Ohio, Texas, and Washington, D.C. stray from the language above, the same conclusion (allowing resignation and/or referral to Rule 1.6 or the equivalent thereof) is reached by reading the comments thereto. In Ohio, the applicable version of this rule states that "[ $t$ ]he discretion or duty of a lawyer for an organization to reveal information relating to the representation outside the organization is governed by Rule 1.6(b) and (c)." See OHIO RULES OF PROF'L CONDUCT r. 1.13(c) (2016). In Texas, Rule 1.13 is silent on its face as to the lawyer's options after referring the matter to the organization's higher authority but Comment 7 thereto indicates that the lawyer may reveal externally after exhausting internal options if permitted by Rule 1.6 (the duty of confidentiality and its exceptions). See TEX. Rules OF PROF'L CONDUCT r. $1.12 \mathrm{cmt} .7$ (1995). In Washington, D.C., Rule 1.13 is also silent on its face as to the lawyer's options after referring the matter to the organization's higher authority, but the comments thereto indicate that confidential information relating to a lawyer's representation of the organization may be revealed only if permitted by Rule 1.6 (the duty of confidentiality and its exceptions). See D.C. RULES OF PROF'L CONDUCT r. $1.13 \mathrm{cmt} .2$ (2007). 
called for the federalization of legal ethics generally ${ }^{248}$ or for uniformity among specific law practice contexts. ${ }^{249}$ The history of state ethical rules as they pertain to corporate attorneys representing organizations is telling in that more recent decades have revealed an increased lack of uniformity in this arena. Prior to the ABA's adoption of the Model Rules in 1983, attorneys who practiced corporate law were subject to a relatively uniform set of ethical obligations, as forty-nine states had adopted the ABA's original Model Code (the precursor of the Model Rules) of Professional Responsibility (the "Code") "with little debate and minor revisions." 250 Although the original rules under the Code did not allow a lawyer to permissively disclose information about a client corporation's misconduct, lawyers had much more discretion under "Preservation of Confidences and Secrets of a Client" Disciplinary Rule ("DR") 4-101(C)(3), which would today be Rule 1.6, to reveal an intent of the client "to commit a crime and the information necessary to prevent the

248. See, e.g., Amy R. Mashburn, A Clockwork Orange Approach to Legal Ethics: A Conflicts Perspective on the Regulation of Lawyers by Federal Courts, 8 GEO. J. LEGAL ETHICS 473 (1995) (discussing the impact of a national federal bar with uniform ethical rules for attorneys); Jonathan M. Weiss, The Need for Federal Solutions to Interstate and International Ethics Conflicts: A Case Study in Confidentiality, 11 J. INT'L BUS. \& L. 1, 34 (2012) (calling for a federal government mandate of a federal code of ethics in the international practice context); Fred C. Zacharias, Federalizing Legal Ethics, 73 TEX. L. REV. 335 (1994) [hereinafter Zacharias, Federalizing Legal Ethics] (predicting in 1994 that the pressure to adopt a federal uniform code of ethics for attorneys would increase as lawyers took on a more national practice and examining the merits and likelihood of adoption of a comprehensive federal code and system of enforcement); see also David B. Wilkins, Who Should Regulate Lawyers? 105 HARV. L. REV. 799, 801 (1992) (noting that, in considering how to effectively regulate lawyers, one must "account for relevant differences among professional norms and among various markets for legal services"). But see Eli Wald, Federalizing Legal Ethics, Nationalizing Law Practice, and the Future of the American Legal Profession in a Global Age, 48 SAN DIEGO L. REV. 489, 546 (2011) (arguing instead for "open border permission" for attorneys to practice across jurisdictions and still be subject to state control to address the "mismatch" between national law practice and state-based regulation).

249. See Cramton et al., supra note 171 , at 810 (noting the desirability of uniform ethical rules "when the application to public companies threatens the integrity of the national market in traded securities"); Desilets, supra note 35, at 615 (expressing the need for a separate code of professional responsibility specifically for the securities attorney); Nancy B. Rapoport, Our House, Our Rules: The Need for a Uniform Code of Bankruptcy Ethics, 6 AM. BANKR. INST. L. REV. 45 (1998) (calling for a uniform and specialized ethics code for lawyers who practice bankruptcy law); Ted Schneyer, Legal Process Scholarship and the Regulation of Lawyers, 65 FORDHAM L. REV. 33,48 n. 72 (1996) (discussing SEC adoption of "its own ethics rules for securities lawyers," which may prompt an increased involvement in ethics enforcement, "perhaps an unwanted task in a time of great budget constraints" (citing Paul Gonson \& John W. Avery, Practicing Securities Law: A Search for Uniformity of Professional Standards, in ALI/ABA COMMITTEE ON CONTINUING LEGAL EdUC., REFORMING LEgal ETHICS IN A REgUlATED ENVIRONMENT 489, 495-97 (Dec. 10, 1993))); Stanley Sporkin, The Need for Separate Codes of Professional Conduct for the Various Specialties, 7 GEO. J. LEGAL ETHICS 149, 152 (1993) (arguing that attorneys in corporate and securities practices would benefit from a separate code of professional ethics).

250. Len Biernat, Corporate Practice: From the Model Code to the Model Rules to the States, 34 ST. LouIS UNIV. L.J. 27, 27 (1989) (discussing the ABA's replacement of the Model Code with the Model Rules of Professional Conduct); see Zacharias, Federalizing Legal Ethics, supra note 248, at 339 (noting that the "initial favorable response to the Model Code was overwhelming," as fortynine states adopted the ABA's Model Code of Professional Responsibility "with virtually no changes" in an attempt to adopt a self-regulatory scheme to govern attorney behavior). 
crime." 251 Such discretion was also visible in DR 7-102(B), which forbade a lawyer to counsel or assist the client in conduct the lawyer knows is illegal or fraudulent and to externally reveal the fraud to "the affected person or tribunal" if the client insisted on its commission, except when privileged. ${ }^{252}$ In addition, Ethical Canon 41 called upon a lawyer who discovered a client's fraud to first "rectify" it by advising the client and then "promptly inform[ing] the injured person or his counsel, so that they may take appropriate steps" if the client "refuses to forego the advantage [ ] unjustly gained.",253

When Model Rule 1.6 was adopted in 1983, it only allowed a lawyer to permissively disclose confidential information to "prevent the client from committing a criminal act that the lawyer believes is likely to result in imminent death or substantial bodily harm."254 By not allowing disclosure to prevent substantial financial injury or to rectify the consequences of crimes or frauds for which the lawyer's services were used, the rule "limit[ed] considerably the discretion and influence that the lawyer once had to prevent" wrongdoing and "significantly chang[ed] the role of the lawyer for the organization" given that most organizational fraud or crime relates to finance and property instead of physical harm. ${ }^{255}$

It is interesting to note that the Model Rules of 1983 were not accepted by the states in the same uniform manner as was the earlier Code, primarily due to resistance by states to limit a lawyer's possible disclosure of client wrongdoing. ${ }^{256}$ California never followed the older Model Code and has not since adopted the ABA's Model Rules. ${ }^{257}$ Furthermore, many states that adopted the Model Rules in 1983 made amendments to them allowing attorneys

251. See Biernat, supra note 250, at 43-44; MODEL CODE OF Prof'L RESPONSIBILITY DR 4-101(C)(3) (1980).

252. Biernat, supra note 250 , at $47 \mathrm{n} .96$. The early version of this provision, contained in ABA Canon of Professional Ethics 41 of 1967, did not include this "except" clause, "which effectively vitiates the disclosure requirements." Id. Thus, lawyers had even more discretion prior to 1983.

253. See id. at 46-47; MODEL CODE OF PROF'L RESPONSIBILITY DR 4-101(C), 7 102(B); ABA CANONS OF PROF'L ETHICS, CANON 41 (1908).

254. MODEL RULES OF PROF'L CONDUCT r. 1.6(b)(1) (1983); Biernat, supra note 250, at 46; see also Alberto Bernabe, Coming Soon to a Law Practice near You: The New (and Improved?) Illinois Rules of Professional Conduct, 39 LoY. U. CHI. L.J. 691, 704 n.59 (2008) (discussing the ABA's amendments in 2003 to Model Rule 1.6, which added new exceptions allowing "disclosure of confidential information to prevent conduct that may result in financial injury, to prevent financial injury and to rectify financial injury"). Compare MODEL RULES OF PROF'L CONDUCT r. 1.6(b)(1) (1983), with id. r. $1.6(\mathrm{~b})(1)-(3)$.

255. Biernat, supra note 250 , at 46 .

256. Id. at 49 (noting that the first states to review the Model Rules of Professional Conduct "rejected many significant recommendations" as the Rules moved from "being mere models to binding rules").

257. Id. at 50-51; see Nicholson, supra note 46, at 94 (noting that not every state has adopted the Model Rules); see also State Adoption of the ABA Model Rules of Professional Conduct, ABA CTR. FOR PROF'L RESP., http:/www.americanbar.org/groups/professional_responsibility/publications/model_rules_of_profession al_conduct/alpha_list_state_adopting_model_rules.html (listing the states that have adopted the Model Rules, among which California is not listed). 
to disclose client information to prevent a crime likely to result in substantial injury to the property or financial interests of another-the rule most likely to apply to wrongdoing by corporate organizations. ${ }^{258}$

States concerned over possible breaches of the duty of confidentiality may consider several mitigating factors associated with the approach to achieve more uniformity among the states as it pertains to external SEC reporting.

First, given that the possible disclosure would by no means be mandatory, the lawyer can undergo the personal decision of deciding whether to proceed. Whether the lawyer decides to reveal such information is likely to depend on his/her normative judgment on a case-by-case basis that considers several factors, including the importance of preserving the confidentiality in the particular scenario, the level of risk to third parties, or other moral considerations. ${ }^{259}$ Moreover, permissive disclosure rules may in fact be more limited than anticipated, as the extent of discretion afforded by them is narrower than would appear given the ability of separate mandatory rules or legal processes to curtail them. ${ }^{260}$ Further, from a reputational standpoint, it is perhaps also likely that, ultimately, in-house counsel would decide not to blow the whistle on the client given the potentially negative social consequences for doing so and the effect this could have on the lawyer's career. ${ }^{261}$

Second, attorneys in the corporate securities practice balance competing interests that affect the feasibility of maintaining the duty of confidentiality in all circumstances. When attorneys are representing the organization as client, many competing factors are at play given the "wide variety of constituencies [that] comprise the corporate entity." ${ }^{262}$ As discussed, the Part 205 Rules apply only to attorneys "appearing and practicing before the [SEC] in the representation of an issuer." 263 An "issuer" is defined as any person (including a company) "who issues or proposes to issue" securities that are registered under the federal securities laws or is required to file reports or registration statements under such laws. ${ }^{264}$ Thus, the attorney-reporting rules apply only to lawyers representing companies in which the investing public plays a significant role in ownership. As such, attorneys who practice before the SEC

258. See Biernat, supra note 250, at 50-69; see Nicholson, supra note 46, at 94.

259. See Bruce A. Green \& Fred C. Zacharias, Permissive Rules of Professional Conduct, 91 MINN. L. REV. 265, 298-99 (2006).

260. See id. at 292-97. Green and Zacharias examine several factors that may limit a lawyer's discretion to permissively disclose, including limits imposed by mandatory ethics provisions and the power of courts or other lawmakers to curtail discretion.

261. See Lobel, supra note 40 , at 1262; see also Cramton et al., supra note 175 , at 808 .

262. Desilets, supra note 35 , at 615 .

263. 17 C.F.R. $\$ 205.3$ (2015) (emphasis added).

264. Id. $\S 205.2(\mathrm{~h})$ (incorporating by reference the definition of "issuer" in 15 U.S.C.A. $\S 78 \mathrm{c}(2012))$. 
are ill-suited to a one-size-fits-all approach as it pertains to the duty of confidentiality that has been largely relied upon by the Non-Adopting States. ${ }^{265}$

Unlike attorneys who represent individual clients, attorneys who appear and practice before the SEC represent an organization, which includes not just individual officers and directors, but also shareholders and the investing public, who have no other advocates acting on their behalf. ${ }^{266}$ The nature of the securities laws, which are built on the premise of protecting investors through full disclosure, mandates that an organization engaged in securities transactions, which may include public offerings or private placement of securities, disclose all material information and act in ways that are nondetrimental to the investing public. ${ }^{267}$ Some of the lawyer's duties in this context may involve structuring and drafting documents to be filed with the SEC as annual or quarterly filings, proxy statements, prospectuses, or press releases. $^{268}$ The role that the attorney plays in this sector is thus uniquely targeted to shareholders and other investors as the main audience of public fillings. ${ }^{269}$

In addition, when the board allows for unlawfulness to continue, arguably it is no longer speaking on behalf of the corporation based on the principle that

265. See, e.g., David B. Wilkins, Legal Realism for Lawyers, 104 HARV. L. REV. 468, 487-88 (1991) (noting the weaknesses in uniformity of ethical standards for lawyers across different practices):

Wide disparities exist between the working conditions, experiences, professional status, and economic rewards enjoyed by different lawyers. Lawyers who represent large corporations are different from those who represent individuals. . As legal practice becomes more specialized and complex, these divisions are likely to increase rather than decrease. Given these differences, the idea that all 800,000 American lawyers share a common professional culture capable of producing uniform answers to ethical problems strains credibility.

Id.; see also Stephen B. Burbank, State Ethical Codes and Federal Practice: Emerging Conflicts and Suggestions for Reform, 19 FORDHAM URB. L.J. 969, 975 (1992) (noting an emerging acknowledgment that "norms of professional conduct may vary depending on an attorney's role"); Fred C. Zacharias, The Restatement and Confidentiality, 46 OKLA. L. REV. 73, 85 (1993) ("[I]t is not gospel that lawyers should act identically when serving in different capacities. . . because perspectives on confidentiality may vary among subgroups of lawyers, a single set of confidentiality rules may be applied unevenly.").

266. Desilets, supra note 35 , at $624-25$ (noting that in such circumstances the securities attorney may be aware of the corporation's fraud and may protect the investing public by disclosing the fraud); Christin M. Stephens, Sarbanes-Oxley and Regulations of Lawyers' Conduct: Pushing the Boundaries of the Duty of Confidentiality, 24 ST. LouIs U. PUB. L. REV. 271, 298 (2005) (noting the importance of the corporate attorney's obligation to the "public at large, as well as to his or her client").

267. Stephens, supra note 266, at 298; see Robert C. Koch, Attorney's Liability: The Securities Bar and the Impact of National Student Marketing, 14 WM. \& MARY L. REV. 883, 898 (1973) (discussing attorney liability in the securities arena as a "reasonable means to implement a primary purpose of the securities laws-protection of the individual investor through full disclosure"); see also James Fanto, Paternalistic Regulation of Public Company Management: Lessons from Bank Regulation, 58 FLA. L. REV. 859, 901 (2006) (noting that the SEC's "basic jurisdiction is company disclosure").

268. See Nicholson, supra note 47 , at 100.

269. Id. 
only authorized conduct can be attributed to the corporation. ${ }^{270}$ In such instances, the lawyer must ensure the corporation is protected. Resignation from representation would seem futile, as the wrongdoing could become more and more egregious, causing further harm to the corporation and its constituents. Furthermore, resignation as the sole option for an in-house attorney would essentially force lawyers to quit their full-time jobs and sacrifice their livelihoods. ${ }^{271}$ Instead, when the board will not act, the lawyer should protect the corporation by informing the governing agency, the SEC, at a time when the misconduct is in earlier stages and can be feasibly remediated. ${ }^{272}$ Such actions reinforce the central tenet of the ethical rule that the organization as a whole is the lawyer's client.

\section{Conclusion}

Despite advances in society that place a newfound respect on whistleblowers, retaliation against such persons remains prevalent. ${ }^{273}$ In-house attorneys who are required by the Part 205 Rules to internally blow the whistle on corporate client wrongdoing have been subject to retaliation in much the same way as regular employees. ${ }^{274}$ Not only do such lawyers face possible disciplinary action by the SEC for failing to adhere to these rules, they experience unique challenges when seeking retaliation protections as whistleblowers. Although attorneys in this context may be eligible for protection under state tort law and SOX, they are likely to face many challenges in obtaining relief under these sources. ${ }^{275}$ Relief under Dodd-Frank, while much more robust, may not be available for internal whistleblowers given the current circuit split in this arena, thereby causing conflict for lawyers who blow the whistle externally if admitted in a state that would not allow the Part 205 Rules's permissive disclosures.

This Article has explored these controversial issues, as well as the question of whether the Part 205 Rules preempt conflicting state law. Given that conflicting state law appears to pose an obstacle to achieving the federal purpose set forth in SOX and that the SEC acted within its delegated authority in promulgating the Part 205 Rules, it is likely that a court would decide in favor of preemption. ${ }^{276}$ As it stands now, corporate and organizational attorneys must navigate a complex web of regulations that governs their reporting options. Adding clarity to the reporting triggers in the Part 205 Rules would

270. See William H. Simon, After Confidentiality: Rethinking the Professional Responsibilities of the Business Lawyer, 75 FORDHAM L. REV. 1453, 1465 (2006).

271. See supra Part II.A.

272. Simon, supra note 270 , at 1465 .

273. See supra Part I.A.

274. See id.

275. See supra Part II.

276. See supra Part IV.A. 
ensure that lawyers have taken all efforts to remedy problems internally before reporting out, and other alternatives, like the adoption of a modified Model Rule 1.13, would ensure that attorneys subject to conflicting rules are protected from retaliation. Given the increased focus on whistleblowing generally and the unique role of attorneys who practice before the SEC in their representation of issuer-clients, ${ }^{277}$ such persons are uniquely poised to play an essential role in modern corporate governance and compliance efforts and should be fully protected for these efforts. 
